
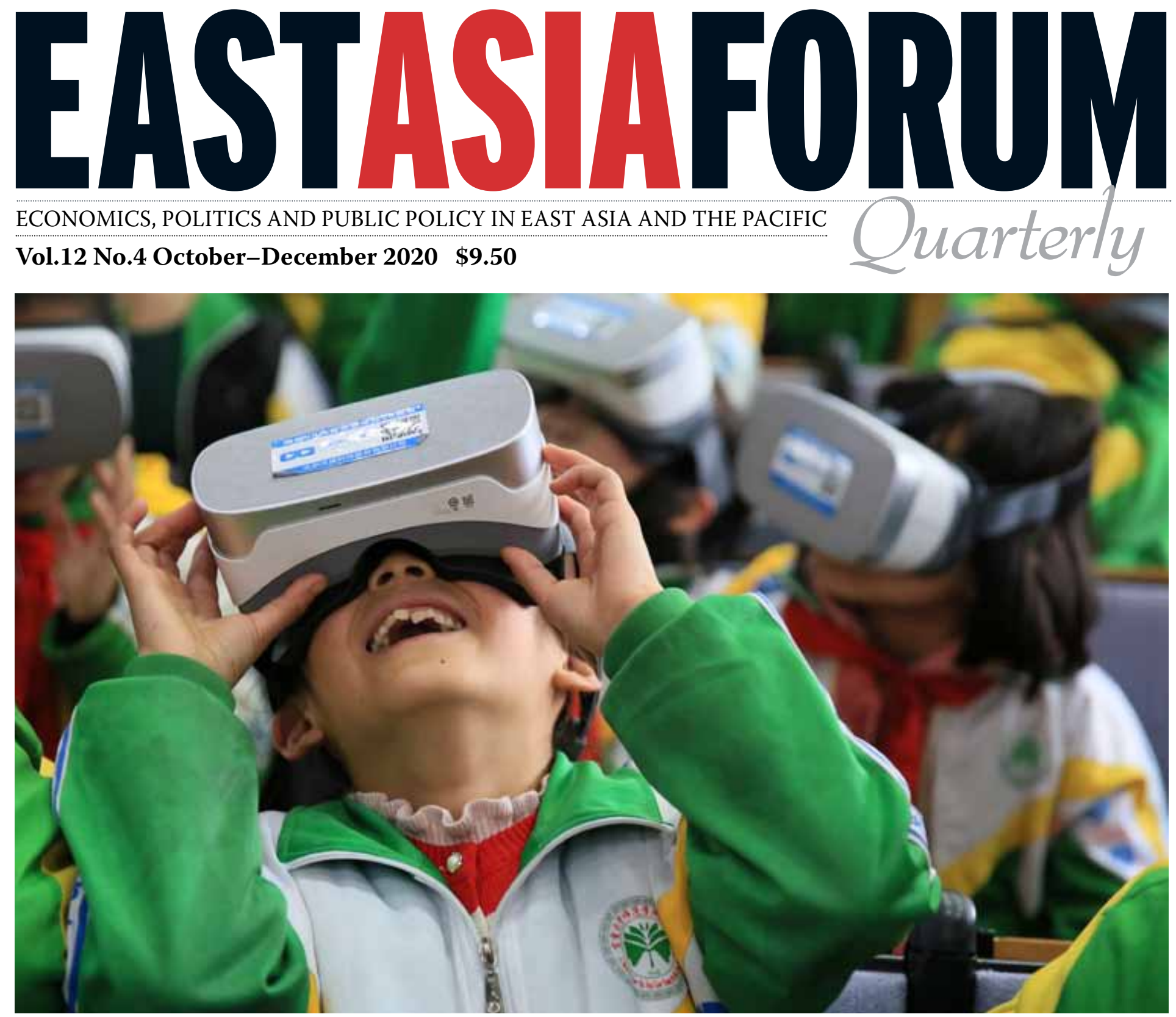

\title{
How China is changing
}

David Dollar Challenges of China's economic transformation

Yao Yang China's bold new Five Year Plan

Jude Blanchette Party the vehicle for Xi's nation-building agenda

Yiping Huang Digital technology transforming China's economy

Isabel Hilton Questions remain over 'eco-civilisation' ambitions ... and more ASIAN REVIEW - Champa Patel: How COVID-19 infected human rights 


\section{EASTASIAFORUM \\ . \\ ISSN 1837-5081 (print) \\ ISSN 1837-509X (online)}

\section{From the Editors' desk}

For many Chinese, the Spring Festival of 2020 is one they will never forget. The holiday began as normal, with hundreds of millions travelling back to their hometowns to celebrate the lunar new year. But the country came to a standstill on 23 January, when the Chinese government locked down the city of Wuhan, the epicentre of a novel coronavirus outbreak.

Since then COVID-19 has spotlighted, like no other event, the importance of an ascendant China in global affairs. The response of China's health system in the early days of the pandemic had international repercussions. China's nationwide lockdown proved effective at containing the disease, in marked contrast with many Western democracies. China's energetic 'mask diplomacy' created geopolitical waves only likely to grow in coming months as leading countries pursue 'vaccine diplomacy' in the developing world. China and the United States sparred over global governance at the World Health Organization.

Inherent to the debates that sprang from these developments is the notion that China is experiencing a period of significant 'change'. Leader $\mathrm{Xi}$ Jinping hails a 'new era' that will see China 'become powerful' and achieve 'national rejuvenation'. Xi's agenda has delivered progress, but has corresponded with a significant change in how many countries view China's rise. Beijing can no longer assume a global environment that's so conducive to its continuing rise, and China's success appears to depend increasingly on the realisation of Xi's domestic agenda.

This issue of East Asia Forum Quarterly examines how China is changing and why the changes are important. On the economy, it includes analysis of the plans and the challenges in China's attempt to become a high-income country with a growth model ordered around consumption, innovation and sustainability. It includes assessments of how the political, military, technological, environmental and strategic dimensions of China's rise have evolved under President Xi.

The Asian Review section offers insights into the future of Kashmir, human rights in Southeast Asia, and global governance reform.

\section{Neil Thomas and Jiao Wang}

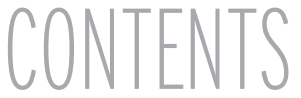

\section{DAVID DOLLAR}

Domestic, global challenges of economic transformation

\section{YAO YANG}

China's bold new Five Year Plan

\section{KERRY BROWN}

How China's state serves the Party

\section{JUDE BLANCHETTE}

Party the vehicle for Xi's nation-

building agenda

13 JOEL WUTHNOW

PLA's capability expands

15 DAVID VINES

ASIAN REVIEW: Asia's stake in

building global cooperation

20 CHAMPA PATEL

ASIAN REVIEW: How COVID-19

infected human rights protection

\section{AYESHA RAY}

ASIAN REVIEW: Kashmir still roiled in conflict

\section{WILLIAM H. OVERHOLT}

China takes a page from the US Cold

War playbook

\section{YIPING HUANG}

How digital technology is

transforming China's economy

\section{ANDREW KENNEDY}

Whither China's technological dream?

\section{SONG HONG}

Multilateralism under stress in

Sino-US trade conflict

\section{ISABEL HILTON}

Questions remain over

'eco-civilisation' ambitions

COVER: A primary school student tries out a virtual reality (VR) headset at a classroom in Xiangxi, Hunan. China is pursuing its high-tech vision under the policies of President Xi Jinping. Picture: Reuters. 


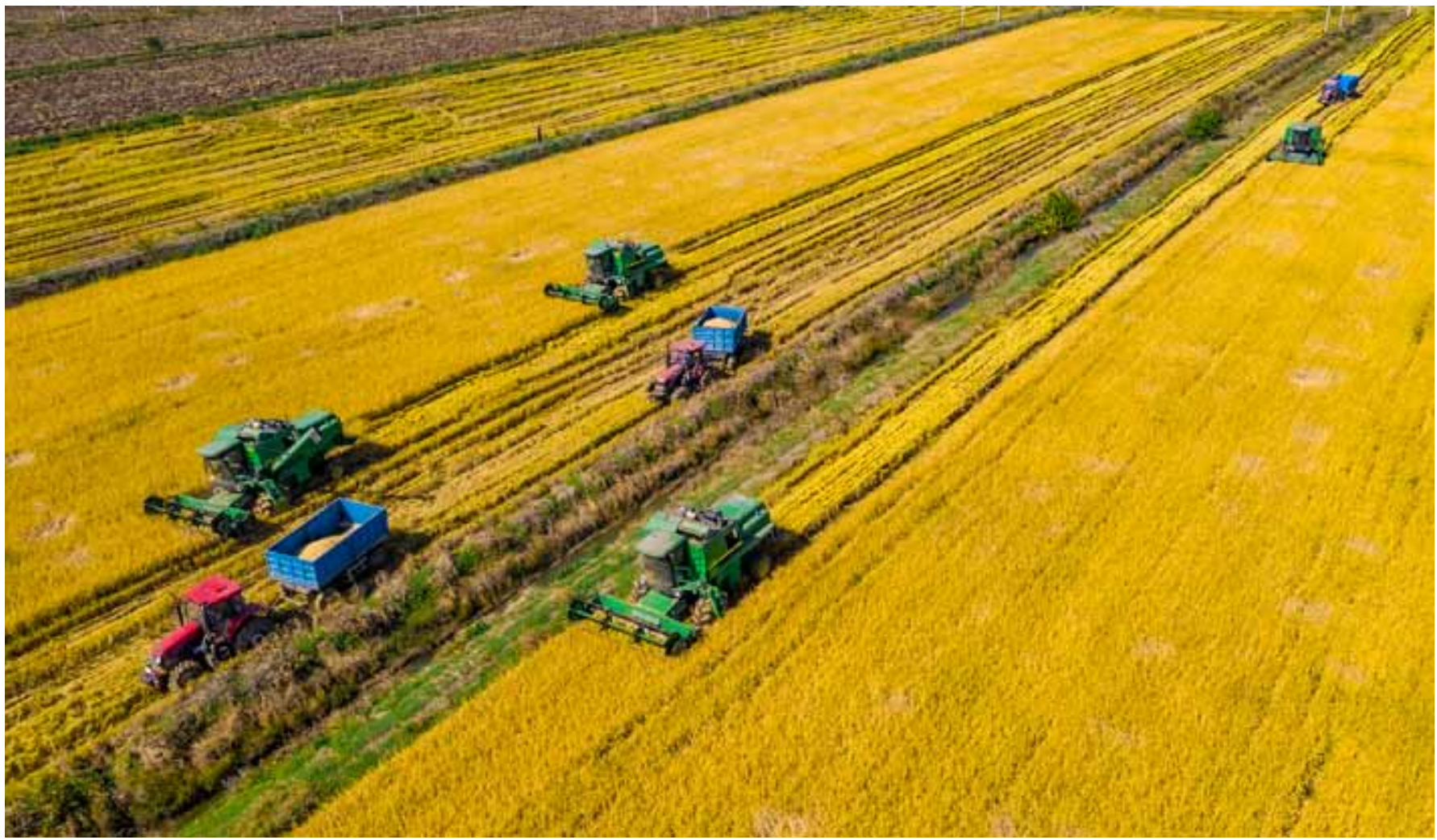

Rice harvesters at work in Jiangsu province in October 2020. China will rely increasingly on automation to overcome a labour-force shortfall.

\section{Domestic, global challenges of economic transformation}

\section{DAVID DOLLAR}

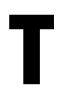
HE story of China's spectacular growth, at around 10 per cent annually for 40 years, is well known, but that story is coming to an end because of both domestic and global factors. There are myriad changes in China's situation, but in analysing its prospects for the next several decades, three particular challenges are striking: the shift from a laboursurplus to a labour-scarce society; the shift from investment to innovation as the primary source of growth; and the shift in China's global position from a rising power to an established power.
Rapid ageing is probably the biggest single challenge that China faces domestically. The population over 65 will increase from about 200 million today to 400 million by 2049 , while the overall population will decline slightly. Within this group, the most rapid rise will be in the population 85 and older: from fewer than 50 million today to more than 150 million in 2049. Taking care of the elderly would be a challenge under any situation, but the challenge is compounded by ruralurban divides.

Most of the elderly live in the countryside, though often their working-age children have moved to cities as migrant workers-frequently leaving school-aged children behind. Since rural health systems are weak compared to urban ones, taking care of the elderly will require a combination of more permanent migration to cities plus strengthened rural service delivery. It is time for China to completely scrap the hukou household registration system that limits permanent migration and to unify rural and urban pensions, health insurance and educational systems. This will be good both for social objectives and the efficient use of labour, which will be a dwindling resource. 
EASTASIAFORUM EDITORIAL STAFF

\section{Issue Editors}

Neil Thomas, Senior Research Associate, Macropolo, the Paulson Institute.

Jiao Wang, Research Fellow, the Melbourne Institute: Applied Economic and Social Research, the University of Melbourne.

\section{Series Editors}

Peter Drysdale, Head, East Asia Forum and East Asian Bureau of Economic Research, Crawford School of Public Policy, ANU.

Shiro Armstrong, Director, AustraliaJapan Research Centre, and Editor, East Asia Forum, Crawford School of Public Policy, ANU.

\section{Editorial Staff}

Coordination: Marie Armstrong. Editing: Nicol Brodie, David Chieng, Benjamin Clarke, Alison Darby, Oliver Friedmann, Annie Gao, Brandon Harrington, Jade Lin, Dorothy Mason, James Naylor-Pratt, Jake Read, Maya Salama, David Wu, ANU.

Editorial Advisers: Peter Fuller, Max Suich.

Production: Peter Fuller, Words \& Pics. Email Peter.Drysdale@anu.edu.au, Shiro.Armstrong@anu.edu.au.

Views expressed are those of individual authors and do not represent the views of the Crawford School, ANU, EABER, EAF, or the institutions to which the authors are attached.

\section{ANU PRESS}

Published by ANU Press The Australian National University Canberra ACT 2601, Australia

Email: anupress@anu.edu.au Web: http://press.anu.edu.au
Dealing with ageing is first and foremost a quality-of-life issue, but it also has economic implications. China's labour force will shrink, but how much and with what impact remains to be seen. As China's workforce shrinks, the 55-64-yearold cohort will increase dramatically. Keeping this group and the 'young olds' (65-85) healthy and active is China's best hope for staving off a dramatic labour force decline. Improving rural education is also critical because about half the workers of the future are going to school in the countryside. Deficiencies in their education will affect China's growth for years to come.

China is counting on robots and automation to come to the rescue as the labour force declines, but it is impossible to make the pace of automation exactly match declines in particular types of jobs. The social safety net and retraining programs will be increasingly important to help people shift as the job picture shifts.

A second domestic weakness that China needs to address is its overreliance on investment and underperformance on innovation. The financial system has adequately channelled resources to investment during China's rapid growth phase, but the state-dominated system is inefficient. Now that China has reached middle-income levels it will need to depend less on investment and more on innovation and productivity growth.

But the bank-dominated financial system favours lending to state enterprises, which have lower productivity and are less innovative than the private sector. One piece of evidence that the old investmentheavy growth model is running out of steam is that the debt-to-GDP ratio rose steadily from the global financial crisis through 2016. This measure of leverage stabilised during 2017-2019, but then has risen sharply again during 2020. If lending is financing productive investment and growth, then this ratio should be stable or slowly rising. The large increase since 2009 is an indication that many poor investments are being financed.

As diminishing returns to investment set in, successful countries naturally rely more on innovation as a source of growth. China has impressive inputs into innovation, with a large share of GDP devoted to research and development (R\&D) and the largest technical labour force in the world. The outputs, however, in terms of successful companies, high-value patents and productivity growth, are less impressive.

The Made in China 2025 industrial policy is trying to direct innovation in 10 key industries. This is an approach that is not likely to succeed but that has caused great consternation among trading partners. China would do better to focus on the foundations of innovation: intellectual property rights (IPR) protection, venture capital, universities, free trade and general subsidies to R\&D rather than ones targeted at particular technologies.

China has benefited

enormously from

globalisation, but

important aspects of the global order are outdated and need reform 


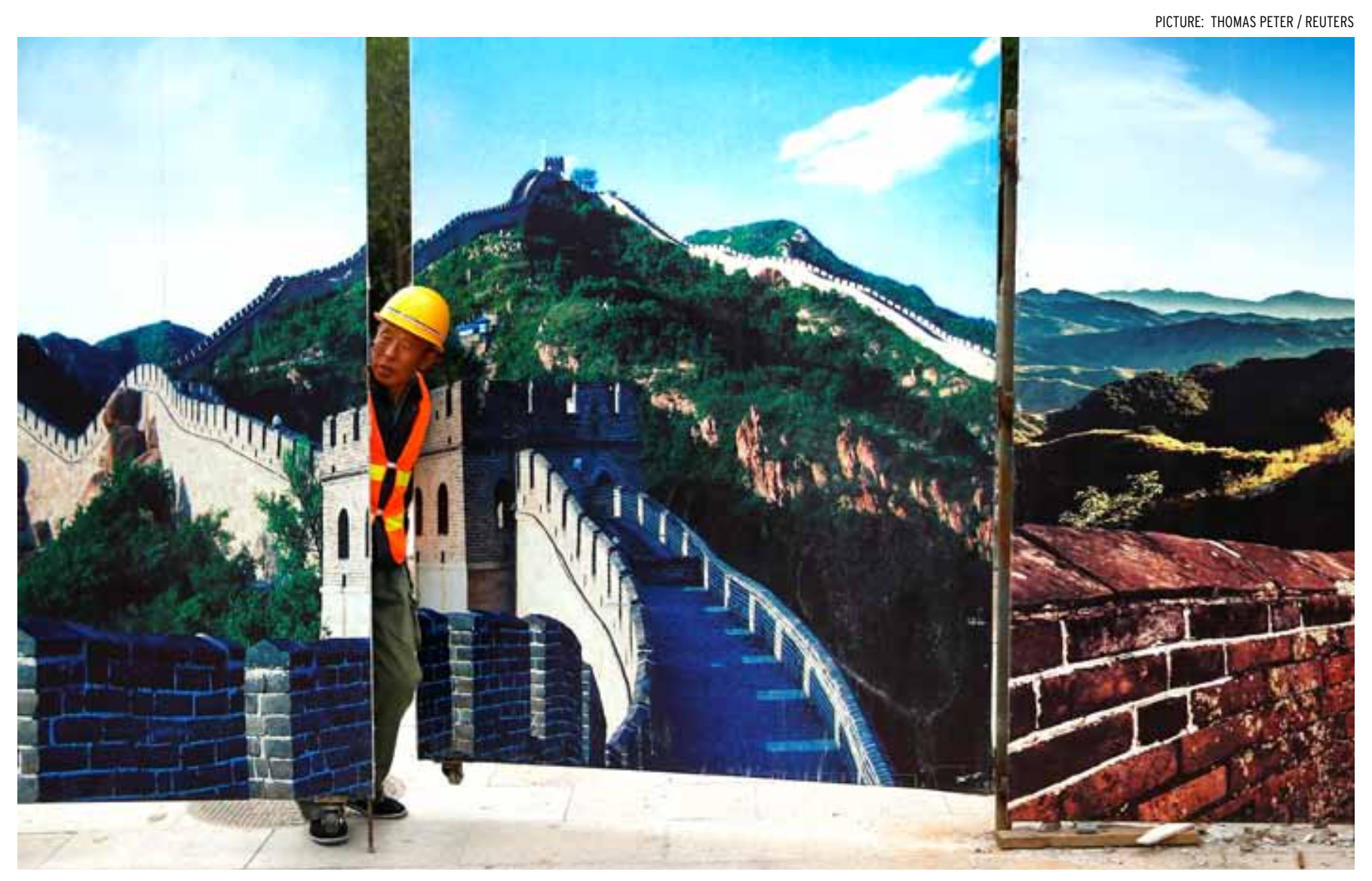

A worker on a Beijing construction site looks through a fence decorated with pictures of the Great Wall. Retraining will be important as the job picture shifts.

A strong innovation foundation combined with ambitious targets to reduce carbon and improve the environment should make China a leader in new technologies to address climate change.

China's ability to meet its social and economic goals will also depend on the international environment and economic architecture. China has benefited enormously from globalisation, but important aspects of the global order are outdated and need reform.

The World Trade Organization is not equipped to deal with modern trade issues such as IPR protection, investment restrictions, cross-border data flows and subsidies. The major economies of the world cannot agree on expanding the resources of the International Monetary Fund because the United States does not want to increase the weight of China and other emerging markets in decision-making, though this is what their growing role in the world economy dictates. China and Western donors have separate and competing programs to finance infrastructure in the developing world.

A strengthening of these economic institutions that provide critical global public goods is required for the world economy to function smoothly. This will require practical compromises between China and the United States, and more generally between developing and advanced countries. China will need to take on more responsibilities commensurate with its great-power status.

Right now, it seems like a joke to talk about practical compromises between China and the United States.
Even with a new Biden administration that will act more cooperatively on the international stage, US-China relations are likely to remain difficult. But we should not take it for granted that China and the United States will become enemies. Both countries have an interest in international cooperation on public goods. For China, domestic reforms that address its main challenges will also be the right foundation for improved relations with the United States and other advanced economies. EAFQ

David Dollar is a Senior Fellow in the John L. Thornton China Center at the Brookings Institution. Previously, he was the US Treasury's economic and financial emissary to China and the World Bank Country Director for China. 


\section{China's bold new Five Year Plan}

YAO YANG

$\mathbf{T}$ HE fifth plenum of the Chinese Communist Party's 19th National Congress, which concluded on 30 October 2020, laid out the guidelines for China's 14th Five Year Plan (202125). It signalled a major strategic shift in China's approach to economic and social development. Four areas of change are particularly significant: autonomous technologies; a new way of urbanisation; equal provision of public goods; and greener production. They will define China's economic future in the next 10-15 years.

'Dual circulation' was proposed as one of the key elements of China's new development framework. Over the past 30 years China has embraced the global economy, and international circulation-international trade, investment and human exchangeshas played a central role in China's remarkable growth. Yet domestic circulation-focussing on building domestic markets-is now being emphasised as a response to the changing international environment.

Based on national security concerns, the United States has geared up its efforts to decouple from China on the technological front. The true intention, as it is widely understood in China, is to slow down or even halt China's technological advancement. The entity list designated by the US Department of Commerce bans American export of hightech components, including highprecision chips, to more than 200 Chinese companies and universities.
The United States has also banned technological transfers to China in dozens of high-tech areas. Huawei has already lost all its supply sources of high-precision chips, and if the ban continues into 2021, Huawei will have to stop its production of high-end smartphones.

Against this background, building autonomous technologies in key areas, including the chips industry, has become the top priority of China's domestic circulation. The government's aim is to increase the share of China-produced chips from its current 25 per cent to 70 per cent within five years. While the United States controls technologies for producing high-precision chips, China can expand its production of low-precision chips, which account for the bulk of industrial demand for chips. China has already increased investment in the chips industry over the past few years. The US ban will only accelerate this process. With the experience accumulated in producing low-precision chips, sooner or later China will be able to produce high-

China's social security and other welfare programs are fragmented, often operating at the county level precision chips.

China will incur higher costs in producing domestically, but US chip companies will also lose a large market and their innovation capacity will be seriously hampered. This US technological strategy will hurt the United States as much as it will hurt China.

The election of Joe Biden as the next US president raises hopes that the US government will change its technology policy towards China. While technological competition between the two countries will not disappear, it is likely that the Biden administration will focus more on raising the United States up rather than holding China back. This gives China an opportunity to build rules-based competition with the United States.

China's urbanisation has lagged behind its pace of economic development. Presently, 60 per cent of residents live in cities, while Japan and South Korea had more than 70 per cent when they reached China's current per capita GDP. China's nonagricultural labour force accounts for 72 per cent of its total labour force. It is reasonable to expect China's urbanisation rate to reach that number too. The government's plan is to increase China's urbanisation rate to 75-80 per cent over the next 15 years.

Most of the new urban dwellers will be concentrated in a few urbanised regions, including the Pearl River Delta and Yangtze River Delta regions, and in Beijing, Tianjin and surrounding regions, among others. The new strategy will greatly change 


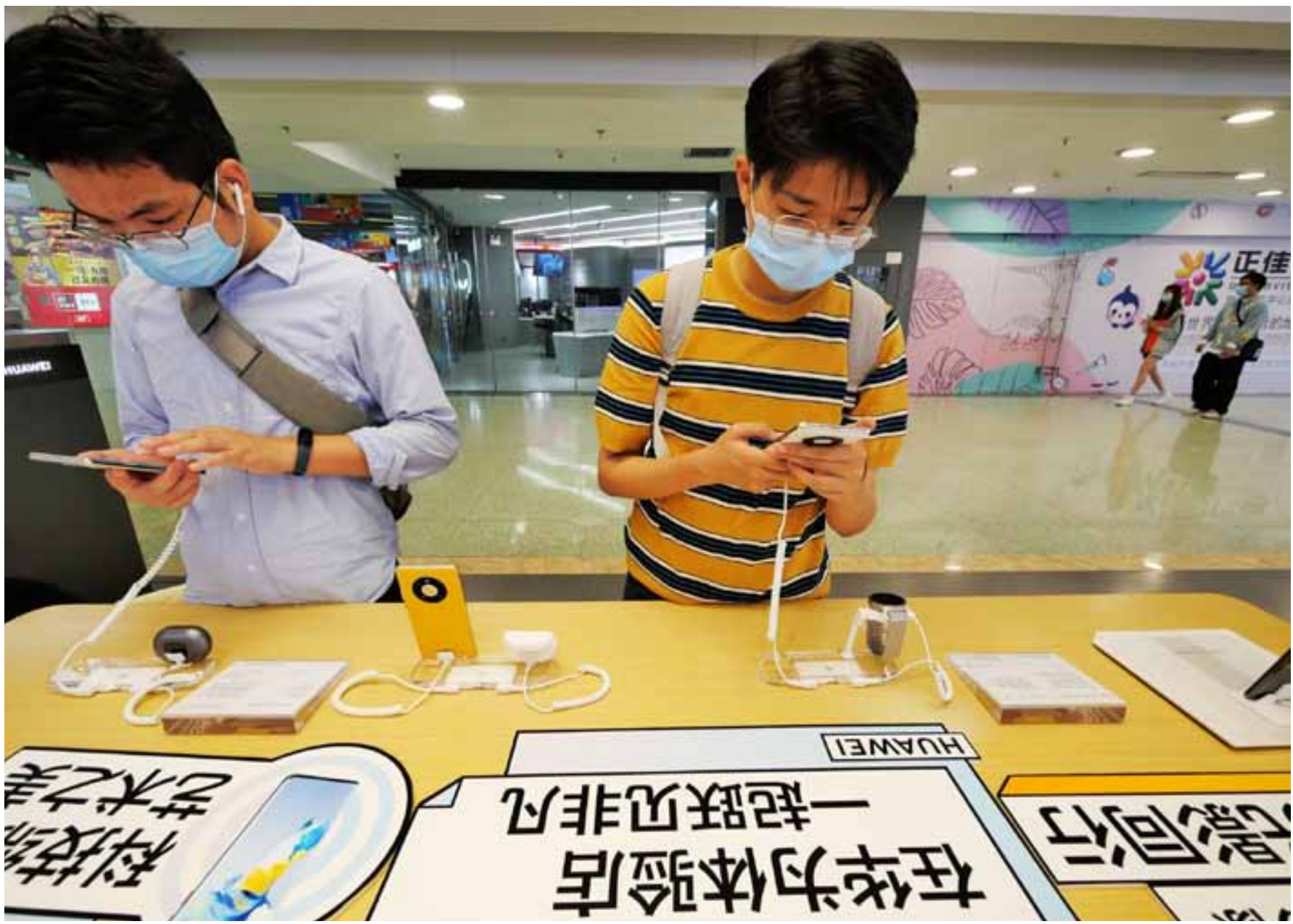

Customers in Guangzhou, Guangdong province, try newly released Huawei Mate 40 series smartphones. Some models, released in November, sold out quickly.

the geographic distribution of China's population and economic activities.

An implication of this new urbanisation strategy is that China will probably have a bifurcated housing sector. While it will face strong headwinds in third- and fourth-tier cities, the housing market in the urban centres will sustain reasonable growth for a longer period of time. Despite repeated government suppressions, the housing sector has remained one of the strongest propellers of China's growth, particularly during recessions.

Accompanying this new drive of urbanisation, China will have to reform its household registration or hukou regulations. Among the 60 per cent of people living in cities, one quarter do not have urban hukou. There were several attempts at reform of the registration system in the past, including one announced by the third plenum of the 18th Party Congress, held in November 2013. But all of them have failed. A key reason was that the reform plans were too radical-they required small cities to unconditionally grant all migrants hukou.

Hukou carries a range of welfare entitlements, ranging from entitlement to buy a car to children's eligibility to college admission. Removing it implies drastic redistribution of welfare and entitlements, and the recipient cities would surely shoulder most of the costs. This is why they have strongly opposed hukou reform plans so far. A more realistic approach is to replace the hukou with a residency card that gradually accumulates welfare privileges. To finally remove the obtrusive effects of hukou, the provision of welfare needs to be equalised across cities.

This is related to the third area of new development introduced by the 14th Five Year Plan.

Despite China's centralised political system, it has the most decentralised fiscal system in the world. Local government spending accounts for 85 per cent of total government spending. Accordingly, China's social security and other welfare programs are fragmented, often operating 
at the county level. Huge regional disparities exist. While cities in the northeast have long incurred deficits in their pension schemes, cities in the southeast coast have accumulated large surpluses.

This fragmented system greatly hampers the sustainability of China's social security system and impedes free mobility of labour across regional borders. The Ministry of Labour has announced its intentions gradually to unify the pension system. Social security contributions are now collected by the tax bureau and partly surrendered to the central government. It is expected that this part will be gradually increased.

To make China's pension system sustainable, it is imperative for the country to raise the retirement age, particularly for women. The current retirement ages are 50 and 55 years, respectively, for female and male blue-collar workers, and 55 and 60 years, respectively, for female and male white-collar workers. These were set in the 1950s when China's life expectancy was barely above 60 . Now life expectancy is 77 and is increasing at about one year every 3-4 years.

China's population is expected to peak around 2028 and the proportion of people aged over 65 is quickly approaching 20 per cent. The baby boomers born between 1962-1976 are ageing quickly and the whole country will face serious challenges in pension and old-age health care. Raising the retirement ages will greatly moderate those challenges, but will face resistance from common people. A realistic approach is to 'run by small steps', by adding nine months or one year every year to the retirement age.

Another task of equalisation is to increase the provision of public goods in the countryside. China aims to become a fully modernised country

\section{International and}

domestic pressures are

increasing for China to

shift toward a greener

economy

by 2035 . Universal coverage of social security is a key feature of modernised countries, but with a deep urbanrural divide, universal coverage based on a single scheme will be a remote target for China even by 2035. More realistically, China should develop a 'unified but multilayer' system that offers a menu of schemes that vary by premiums and corresponding benefits.

Another challenge is to effectively deliver modern amenities to rural residents. Consolidation of villages is the most effective way to overcome the hurdle of cost, but it has frequently caused heated debates. In addition to the issue of properly compensating rural residents for losing their residential land, nostalgia about rural life is another key cause.

The last area of new development is greener production. International and domestic pressures are increasing for China to shift toward a greener economy. Since China joined the World Trade Organization in 2001, 80 per cent of the world's growth in carbon emissions has been contributed by China. This has raised widespread concern. Inside China, awareness of climate change and environmental degradation has also increased.

President Xi Jinping declaimed in a UN general assembly meeting that China's carbon emissions will peak before 2030 and reach net zero by 2060 .
Both are challenging tasks because accelerated urbanisation means that China's energy consumption will greatly increase over the next 15 years. Fossil fuels, mostly coal, still account for 80 per cent of China's energy mix. For China to realise the two goals it must drastically increase energy efficiency. Government agencies have already taken action, with plans for carbon trading and green finance being rolled out. Greener production will prevail in every sector and environmental technologies will become a new hotbed of innovation in China.

Combatting climate change will allow China and the United States to find common ground for cooperation. It is highly likely that climate change will be one of the areas in which Biden will try to build his political legacy, and China's new commitment will help him to build that legacy. Cooperation between the two countries on climate change will foster mutual trust and facilitate the resolution of other challenging issues in their bilateral relationship.

China's 14th Five Year Plan places technological autonomy as one of the country's top priorities. It also signals a shift from pure economic growth to social- and climate-friendly development. The new urbanisation strategy, more equal distribution of public goods and increased investment in environmental technologies will provide new sources for sustainable growth, either by increasing domestic demand or by improving China's economic efficiency. EAFQ

Yao Yang is Cheung Kong Scholar,

Dean of the National School of Development and Director of the China Centre for Economic Research at Peking University. 


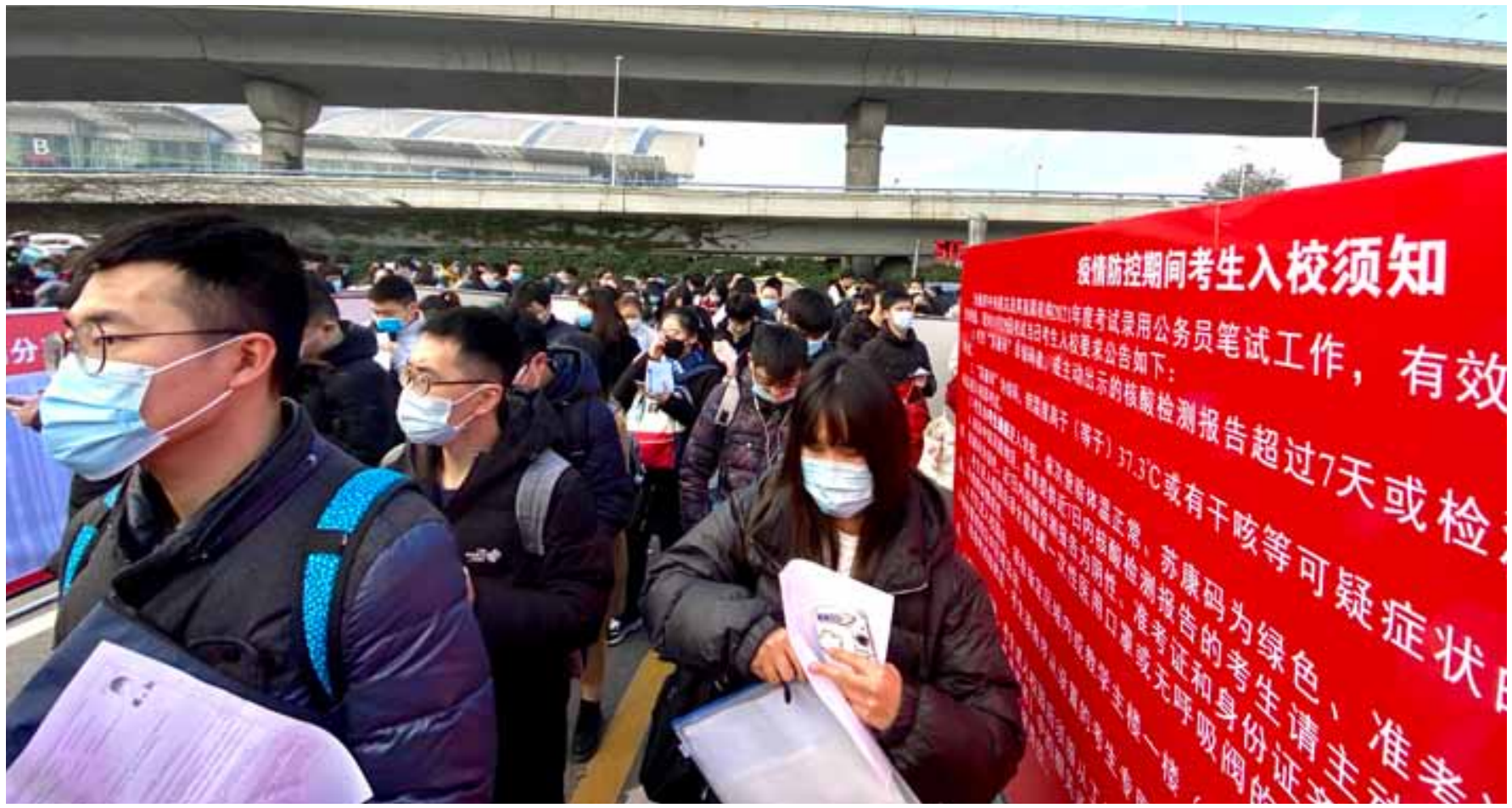

Candidates line up in Nanjing to sit for the National Civil Service Examination in November 2020. An estimated 46 million people work in China's public sector.

\section{How China's state serves the Party}

KERRY BROWN

$\mathbf{X}$ I JINPING is a Party man. His first words in November 2012 after being made General Secretary of the Chinese Communist Party were about closing the gap between the Party and the people. Ever since then, making sure that the Party can indeed create a sustainable governance model-and not be washed away by the forces of history as the Soviet Union was-has been his core task. Despite the vast and ongoing challenges through 2020 because of COVID-19, the Party has never looked more dominant.

That includes over the state. In China, the state exists in many shapes. While those formally designated as 'civil servants' (gongwuyuan) at the national and provincial levels amount to around 8 million, there are almost 60 million working for state enterprises. According to the World Bank, total Chinese public sector employment, including those involved in education, healthcare and other administrative areas, together comes to about 46 million.

Therefore, from an overall employment figure of 770 million, 13 per cent are public sector or state enterprise workers, with the number of state employees more than the membership of the Party, which totalled 90 million in 2019. Despite the view from outside that China is a state-controlled behemoth, the irony is that state employment has a lower share than in the United States, at 16 per cent, or in France at a staggering 26 per cent.

Despite being only a minority employer, the state and public sector still has a commanding role in administration and industries. This is one that the Party continues to control vigorously. In the 1980s, some Chinese leaders said they embraced the market like a 'bird in a cage'-free to develop up to certain limits. These limits were often deliberately left vague and undefined so that changing circumstances could be responded to.

A similar situation prevails between the state and the Party, with the latter controlling the state's political parameters. That, in a sense, is the cage. The state takes Party ideology 
and translates it into implementable policy. It does not have the agency to originate policy or political direction. In the $\mathrm{Xi}$ era, the change has come from making sure that there is real clarity about where the 'cage' that binds the state is.

One key mode of control is simply for the Party to use its powers of appointment in the public and state enterprise sectors to ensure that the state performs as expected. In the era of former president $\mathrm{Hu}$ Jintao, Xi's predecessor, galloping growth meant that officials were often more like entrepreneurs. State-owned enterprises became vast generators of cash, much of which was filtered into the hands of corrupt networks of influence. The state was big business and the Party looked more often like the poorer, more virtuous relative. Now, under Xi, the Party is back.

Any idea of parity, or even subservience, has been expelled. This was largely achieved through the anticorruption struggle that began after the Party's 18th National Congress in 2012, when Hu retired and was replaced by Xi as General Secretary of the Party. The cadres who had misunderstood that their key role was to be politicians-not business people-were disciplined. Some were removed from power. Others were demoted. The signal was clear, though: state workers had their ultimate loyalty to the Party. If they ever forgot that, they risked all. And to those with short memories, in 2020, even in the era of the pandemic, a new anti-corruption campaign has started. This reminds people that their ultimate loyalty must only ever lie with one actor in contemporary China-the Party.

Legal reforms from 2013 have assisted this clarification. The Party's grip on the state means that the state is now much more obedient and likely to follow the rules that it sets down. For those working in the huge nonstate sector, that means at least some benefits. China under $\mathrm{Xi}$ is a repressive place-but it is repressive without favour. Dissidents and rights activists have had a grim time but so too have local and national officials who start to think their state roles give them licence to act any way they wish. In the past, rules were negotiable. Everything could be solved by finding 'the back door' and your networks were your greatest asset.

These days, there are rules. Actions that are seen as eroding the national mission under Xi to become a great, rich nation are seen as akin to high treason. Political obedience has seemingly led to more predictable, rules-based behaviour in the Partystate. It sounds counterintuitive, but in Xi's China, repressive rules cause as much stress for bureaucrats seeking to wander beyond their designated powers as they do for activists wanting to find more areas for social and organised political action. Xi's China is many things, but unpredictable is now not one of them.

$\mathbf{T}$ HE state for $\mathrm{Xi}$ is a stakeholderthe enabler of the grand political vision that his administration has been developing. This is to ensure that China is a great modern nation with global status, having vanquished the demons of instability and fragility from its tumultuous modern history. State enterprises now exist as sources of wealth generation, as well as domestic and external economic action, in order to deliver on this mission. That is why they are regarded with such apprehension as they become active in Western markets.

Their ultimate aim is to deliver the best rewards for their stakeholders-in that they are no different to Western corporations. But there is a crucial difference: the stakeholder is the Party and the value they return is not in economic currency and earnings, but in the much less tangible area of political rewards. Xi's overall political message is a nationalist one: making China great again. This is something to which the state absolutely has to demonstrate commitment. Regulators, ministries and those delivering state services all have to calculate how their work will contribute to this grand, Party-curated and controlled, storyline.

The Party is above all a crisismanagement entity. It performs best when there are crises. Therefore, the vast stress of COVID-19 has shown it at its best. While Western governments have largely floundered, the Party has managed to face down the problem, aided by huge voluntary assistance from the public. It seems to already be pulling out of the worst of the economic downturn, with more than 4 per cent growth predicted by some for 2020.

All of that means that the Party has yet more political capital in its coffers. The state is even more embedded and driven by the Party narrative. Those in China who need to relate to the stateand that means practically everyonehave to ensure that while they seem to be dealing with a strengthened and more confident state apparatus, they know that through that they see the invisible, but undeniable and irrevocable, hand of the Party. China is a complex place, but in this respect it is as simple as $\mathrm{ABC}$. EAFQ

Kerry Brown is Professor of Chinese Studies and Director of the Lau China Institute at King's College London and Associate Fellow with the Asia Pacific Programme at Chatham House. 


\section{Party the vehicle for Xi's nation-building agenda}

JUDE BLANCHETTE

N EARLY eight years into his tenure as General Secretary of the Chinese Communist Party (CCP), Xi Jinping continues to defy easy categorisation. Often likened to the unpredictable and volatile Mao Zedong, Xi sees iron-clad domestic stability and political discipline as paramount. Viewed as an unrepentant nationalist, $\mathrm{Xi}$ has also adopted a decidedly internationalist outlook, seeking to expand China's engagement with-and construction of-multilateral institutions, as well as promoting Chinese investment and financing to all corners of the globe via his Belt and Road Initiative.

Widely criticised for backtracking on domestic economic reforms, Xi has overseen the marketisation of China's industrial policy via newly expanded government guidance funds and, more recently, opened up swathes of China's financial services sector to foreign investors.

Rather than demonstrating incoherence or hypocrisy, $\mathrm{Xi}$ is following in the footsteps of previous Chinese leaders-particularly Deng Xiaoping-who defied cleanly demarcated intellectual categories, instead preferring the Marxist dialectical approach of finding synthesis from seemingly opposing concepts or ideas.

And so, on a slew of critical 'either/or' questions about China's evolving political system and the country's growing influence in the world, the answer to 'what does

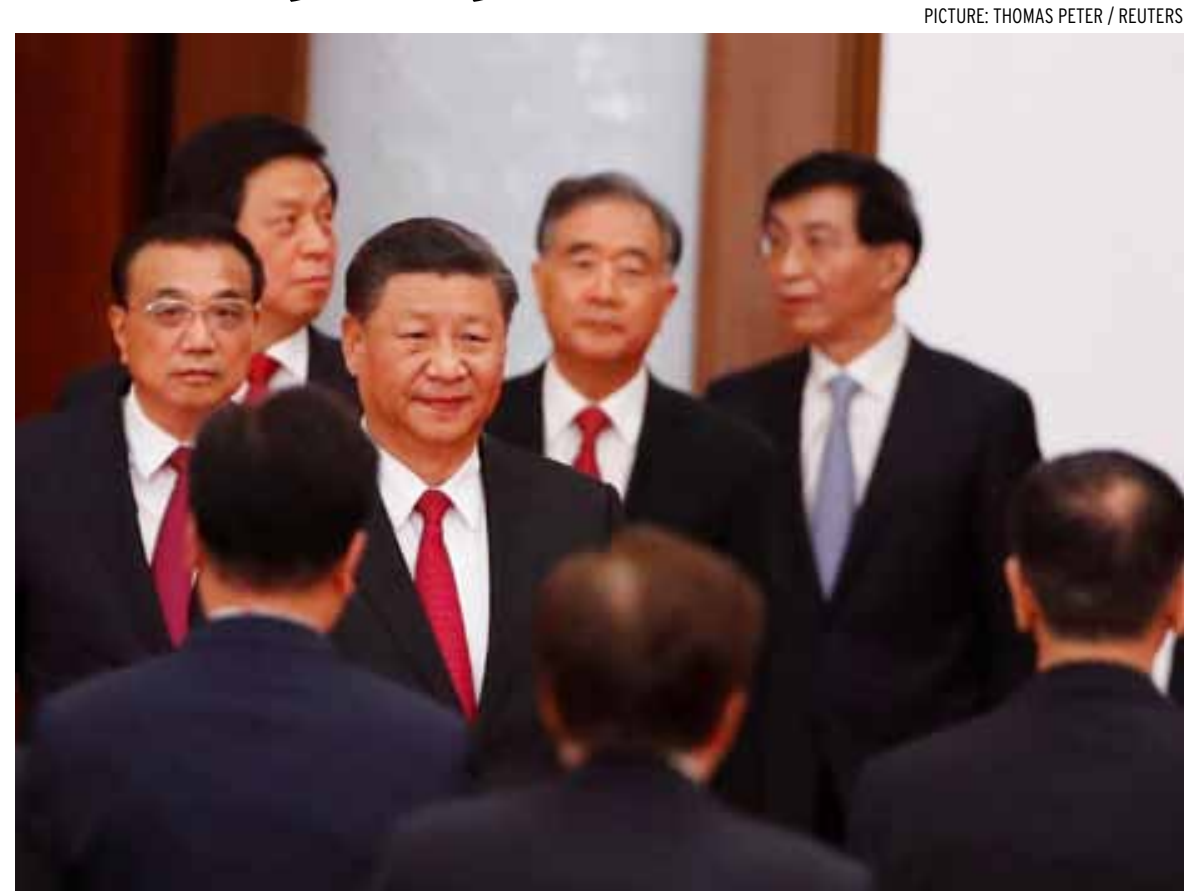

President Xi Jinping and senior political leaders arrive at the Beijing National Day reception on 30 September, 2020, the eve of the 71st anniversary of the founding of the People's Republic of China.

$\mathrm{Xi}$ Jinping believe?' isn't one or the other, but rather, 'yes.' Does he believe in centralised state planning or decentralised markets? Yes, both. Does he want to 'make China great again' through an aggressive nationalist domestic agenda, or is he seeking to expand the country's influence within multilateral institutions? The answer, again, is yes, both.

Perhaps the most interesting aspect of Xi's dialectical approach to China's domestic and foreign affairs is his vision for the evolving role of the CCP. Whereas many external observers (and a good number of Chinese) see an omnipresent Leninist Party-state as an impediment to China's technological and global aspirations, $\mathrm{Xi}$ Jinping sees the Party as the prerequisite for
China's future.

The pursuit of this Party-dominated modernity may well be the most impactful element of Xi's legacy, and the one that arguably introduces the most significant risks to China's continued rise.

As has been well documented, $\mathrm{Xi}$ Jinping came to power with an agenda to save the Communist Party from internal decay, cadre decadence and governance dysfunctionality. Saving the Party, in turn, was critical to Xi's ambitions for China's continued global rise, a goal made concrete at the 19th Party Congress in 2017 with his call for China to become a 'global leader in terms of composite national strength and international influence' by 2049 .

Starting early in his 
administration-29 January 2013 to be exact-Xi began to outline and implement his agenda of aggressive 'Party Building', the systematic approach to strengthening and reinforcing the organisational resilience of the CCP at all levels. His campaign touched all areas of the CCP, from stepped-up political training to the entry-level requirements for member candidates. His anticorruption campaign investigated millions, sanctioned hundreds of thousands and imprisoned some of the CCP's highest-ranking officials. His ideological campaigns signalled to cadres that intellectual pluralism was a threat to the Party.

New policymaking entities, such as Leading Small Groups, began to claw policy authority away from the State Council, instead channelling decisionmaking over more quotidian governing affairs into the Party apparatus, a redrawing of the lines of authority that reached its apotheosis in March 2018. His 'original intentions' campaign attempted to change the way the Chinese people saw the Party, hoping they would view CCP members as stalwarts of the national interest, not rent-seeking parasites.

Further, the Party is now everywhere, or as $\mathrm{Xi}$ is fond of saying, 'Government, the military, society and schools, north, south, east and west-the Party leads them all'. The cellular structure of the Party-its network of party organisations-has been reactivated and reinvigorated to ensure there are no blind spots, areas potentially out of view of the Party apparatus. And the Party has grasped firmly on to the new, and often terrifying, Orwellian capabilities of modern-day communications and surveillance technology, pushing out the CCP's field of view to even the most obscure corners of China's vast territory and variegated population.

Why did Xi take on this task with such urgency, when previous Chinese leaders did not? Without resorting to pop psychology, it's clear from Xi's speeches and writings that he is obsessed with the collapse of the Soviet Union, a historical interest shared by Russian President Vladimir Putin. Of course, this has long been an area of acute study by the CCP. As the People's Daily clarified in October 2013, 'for more than two decades, socialist China has never stopped reflecting on the destruction of the Soviet communist party and state by Soviet Communists'.

But Xi clearly saw that if the CCP was to avoid the fate of the Soviet communist party, it would need to do two things: begin systemically addressing ideological, institutional and political deficiencies of the CCP as an organisation and, equally as important, create a political climate where no Gorbachev-the architect of Soviet demise in Xi's eyes-would ever be permitted to rise to power.

Like Zhou Enlai's quip about the French Revolution, it's too early to

China's international

environment and global

development space

has recently begun to

constrict as countries

react to the full realisation

of Xi's governance model tell if Xi's organisational intervention will be successful or not. The year 2049 is nearly 30 years away, and the past four years have shown that geopolitical tectonic plates can shift unexpectedly and with great consequence. Or as Mike Tyson put it memorably, 'Everyone has a plan till they get punched in the mouth'. What is already clear is that the CCP is a fundamentally different organisation under $\mathrm{Xi}$ than it was before, both in terms of the role it plays in society, and the political and ideological expectations that come with membership.

This resuscitation, even if it does reposition the CCP for longer-term rule, has come at an extraordinary price. Intellectual discourse in China has been eviscerated, a casualty of Xi's campaign against 'historical nihilism' and his many other ideological interventions. The political climate in China is as closed and conservative as it has been since 1989, and of course in China's western frontiers, a million or more Chinese citizens are living under a technologically enabled, neo-totalitarian surveillance state. Finally, China's international environment and global development space has recently begun to constrict under the increasing regulatory and political scrutiny as countries around the world-the United States most prominently-react to the full realisation of Xi's governance model.

Can China change direction? Can a more moderate and tolerant $\mathrm{CCP}$ return? The answers to these questions may be inextricably linked to another: how long will Xi Jinping remain in power? EAFQ

Jude Blanchette holds the Freeman Chair in China Studies at the Center for Strategic and International Studies (CSIS), Washington DC. 


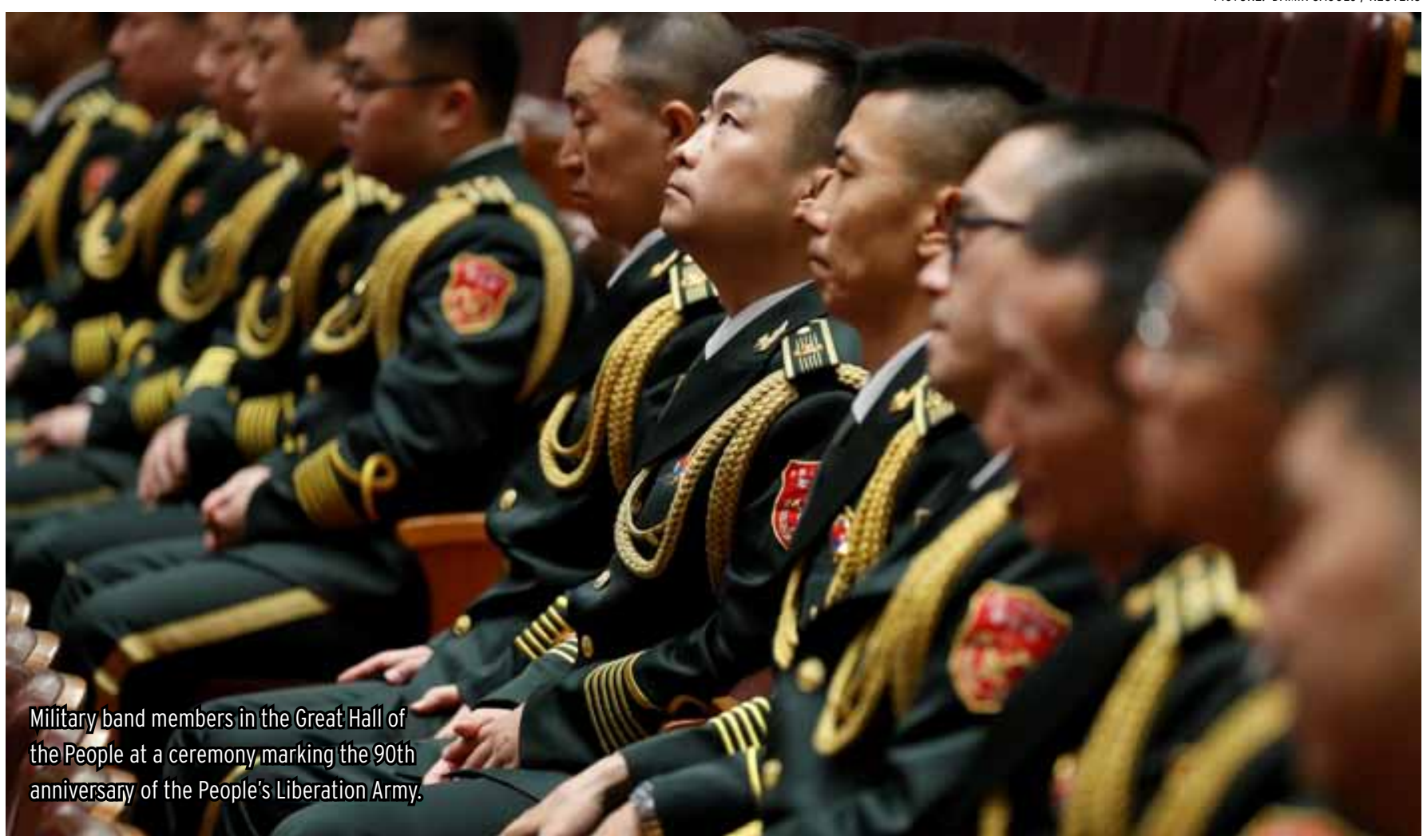

\section{PLA's capability expands}

\section{JOEL WUTHNOW}

- HINA'S military modernisation

- began long before Xi Jinping became Chairman of the Central Military Commission in November 2012, but the pace and scope of that effort has greatly accelerated under him. Key changes include the introduction of advanced weapons and equipment, structural reforms to make the People's Liberation Army (PLA) a more effective force, and a campaign to root out corruption and improve Xi's control. This has given China greater confidence to press its territorial claims with a range of regional rivals.

The PLA was once a poorly outfitted force that aimed to win land battles through guerrilla tactics and attrition. Chairman Deng Xiaoping, focussed on reviving the economy, famously relegated the military to the last of the 'four modernisations'. Beginning with Jiang Zemin (19892004), the PLA pivoted toward deterrence and preparations for 'local wars' against regional opponents. This implied a need for more capable air and naval forces as well as expanded conventional missile forces, accompanied by changes in training, doctrine, recruitment and education.

The limited political influence of Jiang and his successor $\mathrm{Hu}$ Jintao (2004-2012) over the military meant that the PLA was able to resist certain aspects of reform. One problem was that the PLA held on to a 'big army' mentality: ground force officers held most PLA senior positions and the other services were poorly integrated into the command structure. Another problem was that top party officials were unable to rein in prolific corruption, a product of PLA autonomy granted by Deng in return for its willingness to accept low budgets in the 1980s. Xi's arrival heralded an acceleration of modernisation and solutions to problems that had confounded his predecessors. While many had their origins under Jiang and $\mathrm{Hu}$, a number of key systems came online in the $\mathrm{Xi}$ era, including the indigenous aircraft carrier Shandong, the Type-055 guided missile destroyer, the J-20 stealth fighter, the Y-20 long-range transport aircraft, the DF-21D anti-ship ballistic missile, and the DF-17 ballistic missile fitted with a hypersonic glide vehicle. 
Through stronger collaboration with the civilian science and technology community, the PLA also put greater emphasis on new capabilities: artificial intelligence, quantum computing and big data. This reflected a shift to what the PLA terms the 'intelligentisation' of the modern battlefield.

While Xi took credit for programs begun under his predecessors, his careful political manoeuvring allowed him to push through innovative organisational changes that eluded Jiang and $\mathrm{Hu}$. From the beginning, $\mathrm{Xi}$ was a far more visible presence in the PLA, often visiting units and giving speeches on military affairs canonised in 'little red book'-style required readings for troops. He also intervened in promotions down to the level of corps commander, ensuring that those with his vision would occupy key positions.

A key part of Xi's political strategy was expanding an anti-corruption campaign that had begun under $\mathrm{Hu}$, netting several thousand 'tigers and flies'-senior and lower-level officers accused of graft. This campaign ostensibly served to encourage professionalism, but also targeted officials appointed by Jiang, including former Central Military Commission vice chairmen Xu Caihou and Guo Boxiong. Their removal led Xi to selectively eliminate opponents of reform, cementing his personal authority and allowing him to push through controversial restructuring. This campaign was complemented by structural changes, such as the breakup of the notoriously corrupt general departments, that further enhanced Xi's authority within the military.

Xi used his influence to push through controversial changes that ultimately benefited the PLA's operational effectiveness. The topheavy command arrangement modelled on the Soviet military of the 1950s was replaced by a modern structure more like the current US joint command system. A Joint Staff Department oversees five regional theatre commands, each having authority to plan, train for and conduct operations tailored to specific regional missions. The Eastern Theatre Command handles operations against Taiwan, for instance, while the Southern Theatre Command oversees the South China Sea. Signalling a deeper 'joint' mentality, more naval and air force officers now occupy senior positions in the theatres.

\section{$\mathbf{T}$} HE creation of two support forces complemented these new arrangements. The Strategic Support Force consolidated PLA capabilities in the space, cyber, electronic warfare and psychological warfare arenas. This development gives the PLA a powerful tool to pursue operations in the information domain. A new Joint Logistic Support Force created a more centralised and efficient structure for logistics support for operational commanders. There were also a variety of 'below-the-neck' changes, including the shift from army and air force divisions to brigades, designed to increase the PLA's manoeuvrability and interoperability. From 2015 to 2019 the PLA's attention turned inwards. Large-scale exercises were postponed as the PLA focussed on getting the new system right, and China was cautious in provoking dangerous incidents with its neighbours. Reform was what the PLA referred to as a 'complex systems engineering project', made even more complicated by the anti-corruption investigations. The result was a military better manned, organised and equipped to implement Chinese policy domestically and in the region. In 2020, a year that marked the end of this round of reforms, the 'new' PLA led China's response to COVID-19 in Wuhan. It also conducted an unprecedented range of provocations towards territorial rivals: India, Japan, Vietnam and Taiwan.

In 2020, Chinese officials designated 2027-the centennial anniversary of the PLA-as the year in which China will field a 'fully modern military'.

This involves the introduction of big-ticket items, including additional aircraft carriers and a redesigned longrange bomber. The PLA should also be expected to make more subtle changes that promote effectiveness, such as a new generation operational doctrine. China will also continue to research, develop and incorporate innovative technology into the PLA's force structure, and to recruit personnel with the know-how to operate them.

All this implies growing confidence operating in the region and even further afield as the PLA's ability to project power expands. Whether it includes a shift to armed conflict depends not only on the PLA's progress in meeting its modernisation goals, but also the ability of the United States and those in the region to keep ahead of the curve through new capabilities and doctrine. It equally depends on the political resolve of leaders on all sides to avoid escalation. EAFO

Joel Wuthnow is a Senior Research Fellow in the Center for the Study of Chinese Military Affairs at the National Defense University, Washington DC.

The views expressed are the author's and do not necessarily reflect the position of the NDU, Department of Defense or the US Government. 


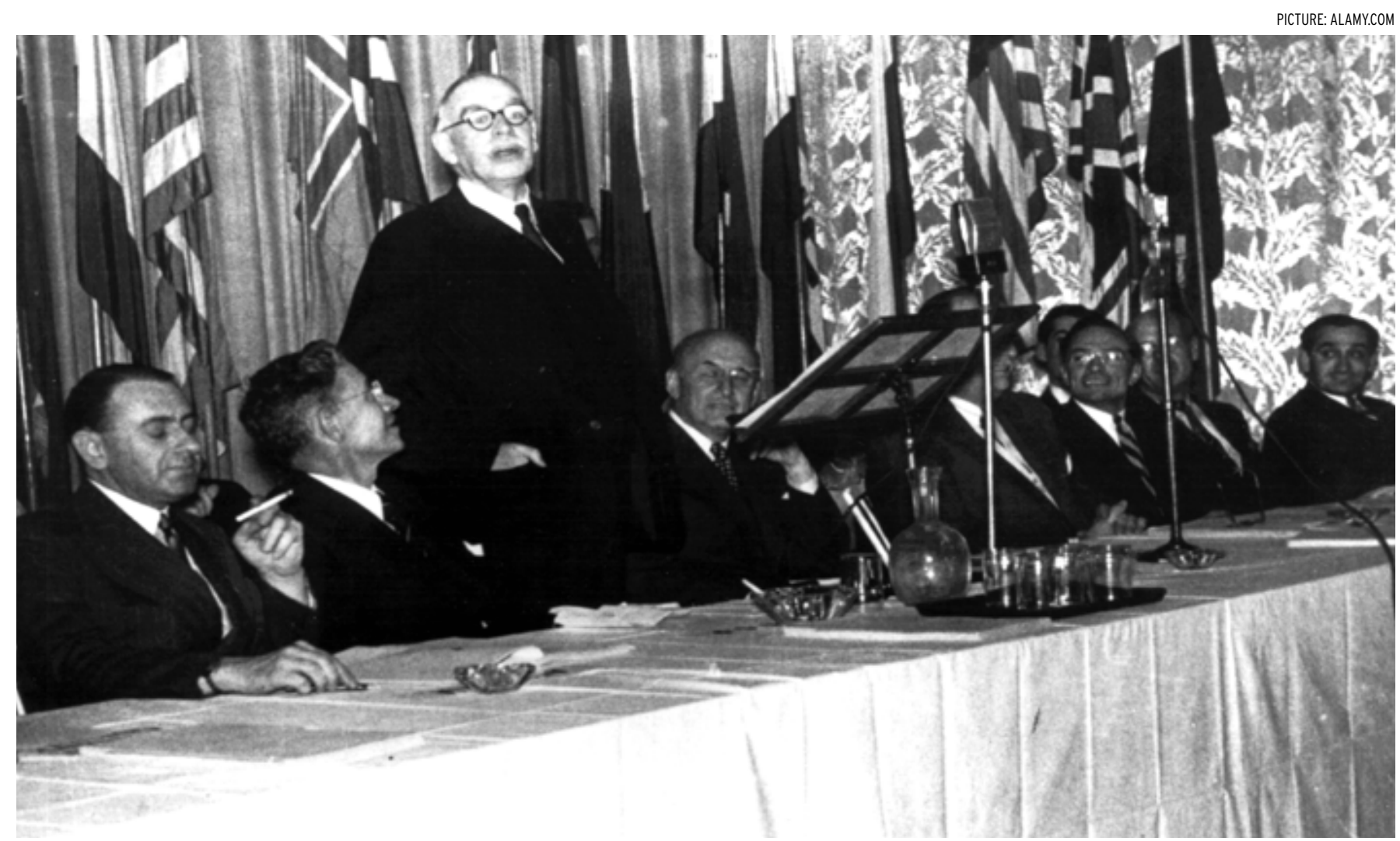

British economist John Maynard Keynes addressing the Bretton Woods conference in 1944, 'an extraordinary burst of institutional creativity'.

\section{Asia's stake in building global cooperation}

DAVID VINES

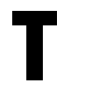

HE last time the world faced challenges as serious as those we now face was at the end of the Second World War. At that time there was an extraordinary burst of institutional creativity. The Bretton Woods conference in 1944 led to the creation of the International Monetary Fund (IMF) to ensure international financial stability. It also led to the establishment of the World Bank as an institution that would lend money to emerging market economies, which were then in Europe and Asia.
A year later the United Nations (UN) was founded at a conference in San Francisco, and subsequent international negotiations led to the establishment of the General Agreement on Tariffs and Trade (GATT), which nearly 40 years later became the World Trade Organization (WTO). Then, in 1948, the World Health Organization (WHO) was established as part of the UN, and the United States started to provide additional money for countries in need though the Marshall Plan.

After the First World War things were very different. Although the
League of Nations was established in 1920, it never gained the necessary authority. First the world slid into the Great Depression of the 1930s, then it lurched into the Second World War.

Seventy years on, these postwar institutions still provide a framework within which international cooperation can take place. But, in the wake of the COVID-19 pandemic, they need strengthening and reinvigorating. The world now faces an important choice. We can do what the world did in the late 1940s, when the institutional choices that were made helped to support a golden 
age of global growth throughout the 1950s and 1960s. Or we could return to the path of the 1930s, when weak cooperation and ineffective institutions led, eventually, to war. The election of Joe Biden as the 46th president of the United States has sparked hope that, once again, the United States might lead the world in the second direction.

For the multilateral system to survive, three areas need to be addressed: global public health, macroeconomics and finance, and international trade.

The international provision of resources for the improvement of global public health is a major global challenge. The pandemic has created a global medical crisis. Cooperation in this area is vital and the international response to the pandemic has so far fallen short precisely because cooperation has been lacking. Many of the tasks involved in controlling an infectious disease like COVID-19 can only be delivered through global cooperation. This includes the distribution of COVID-19 diagnostic tests, the provision of personal protective equipment and the discovery of a vaccine. The international distribution of vaccines will be important in ensuring everyone has access and also in preventing citizens in one country being confined due to a lack of vaccination abroad.

Until now, many such activities have been under-funded and underprovided. The WHO has been particularly under-resourced because it depends on contributions and is unable to charge for its services as the IMF and the World Bank can. Fixing this fault-line will require major reform in the longer term.

Economically, the major immediate need is for international macroeconomic cooperation. There is a worldwide need for huge fiscal support in response to COVID-19 to pay for virus-fighting action and to preserve the incomes of firms and workers until economic recovery comes. The fiscal responses of the world's major economies have been enormous, with spending and revenue measures larger than ever before.

In Australia and the United States, spending and revenue measures have increased by more than 10 per cent of GDP, and in Japan, Canada and South Africa by more than 5 per cent. Loans and guarantees have increased by 15 per cent of GDP in France and the United Kingdom, and by over 30 per cent in Germany and Italy. Across the G20 as a whole, spending and revenue measures have amounted to over 4 per cent of GDP, and loans, equities and guarantees to more than 5 per cent.

But many emerging market economies and developing countries have been denied this course of action due to high levels of public debt and external financial constraints. Global cooperation is urgently needed to support them.

The benefits worldwide would be very large. In countries where extra fiscal support is provided, GDP would increase by more than 2 per cent and employment by up to 5 per cent. Global output would be pulled up by as much as 1 per cent of global GDP.

Such fiscal stimulus would create an additional US $\$ 3$ trillion in government

The major international

economic problems are not only macroeconomic, they also concern trade debt worldwide over five years. The countries carrying out this stimulus will need global support. Without it they face an attack on their foreign exchange markets and risk to their domestic fiscal finances, including the possibility of bankruptcy. Some combination of enhanced IMF lending, central bank swaps and debt relief will be necessary, coupled with sufficient confidence in the future of these countries for the private sector to continue lending.

The effects of COVID-19 on the world's poorest countries have been particularly severe, with the combination of domestic lockdowns and the spillover from the global recession causing immediate and severe hardship across Africa. The scale of the economic shock exceeds anything countries in the region have experienced outside of conflict and puts at risk the gains in human development posted across subSaharan Africa in the last 25 years.

These countries are now in a catastrophic external position, something that is likely to require them to embark on massive fiscal austerity at just the wrong time. An immense increase in overseas development assistance (ODA) will be required to help these countries deal with the medical and fiscal problems thrust upon them.

Keeping the degree of domestic fiscal adjustment within reasonable bounds-those that seem politically feasible-would require an extra US $\$ 50$ billion of ODA, double the current amount. They would need three times as much aid if the aim was to fully isolate them from the COVID-19 shock. This is less than 0.5 per cent of the US\$10 trillion that has been spent to combat the pandemic in G20 countries, but it creates a massive agenda for the World Bank and for the 


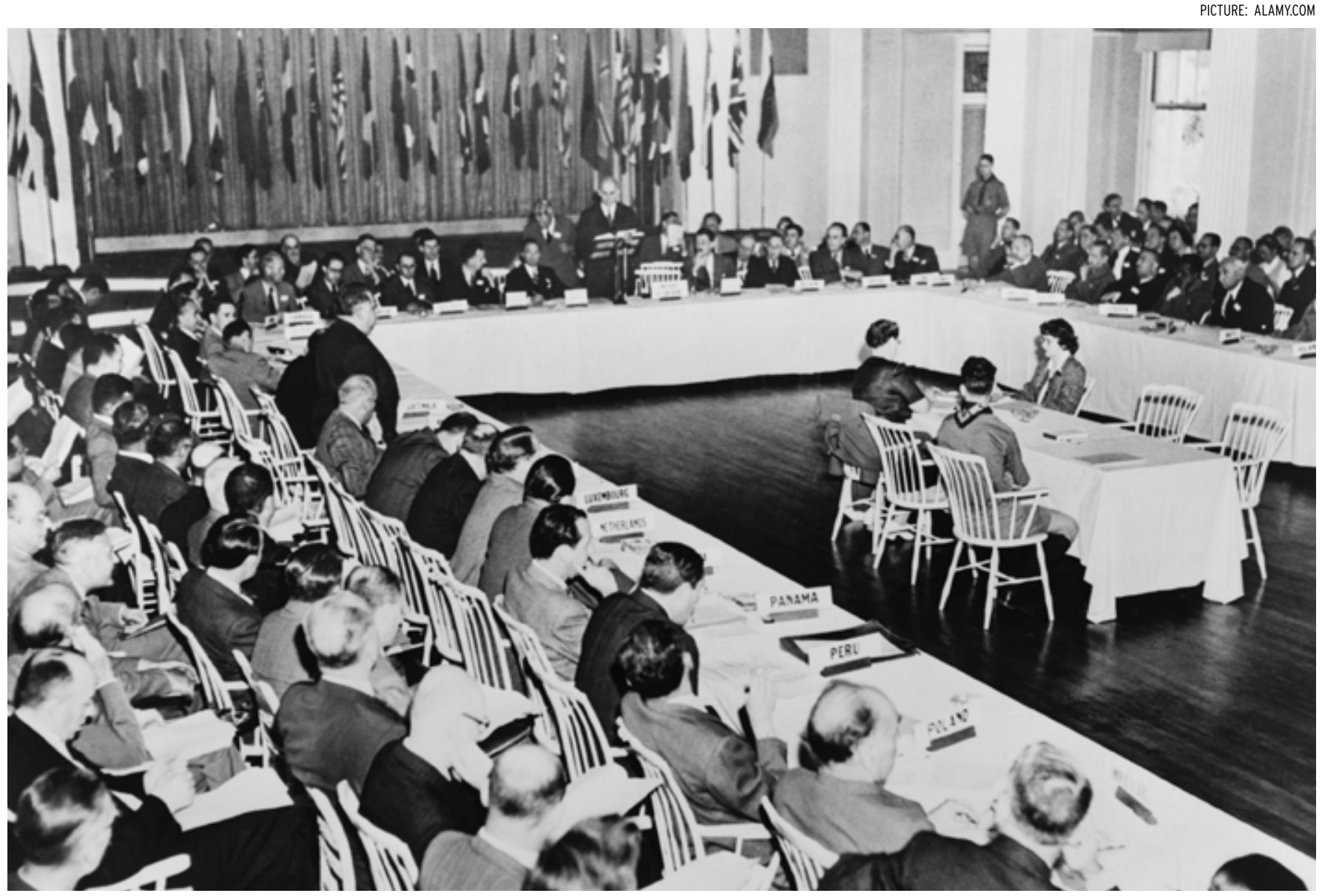

Bretton Woods in session in 1944. The conference put in place the framework that supported 'a golden age of growth throughout the 1950s and 1960s'.

process of international debt relief. And the problem goes far beyond subSaharan Africa. The challenges here will also be long-lasting.

The major international economic problems are not only macroeconomic, they also concern trade.

The experience since the Second World War has been that countries develop most rapidly when they open themselves to international trade, allowing foreign firms to compete with domestic production and especially by encouraging domestic firms to grow by exporting to foreign markets.

This was the miracle that East Asia saw in the 1980s and early 1990s, when South Korea, Taiwan, Malaysia, Singapore and Hong Kong grew with spectacular rapidity by serving world markets. And it has been the astonishing achievement of China over the last 40 years to grow so rapidly to become the second largest economy in the world, bringing half a billion people out of poverty. Such openness has worked well as a development model when combined with strategic coordination of trade and industrial policies. This includes tariff protection of infant industries in the early stages of industrialisation, state support for emerging industries and state-guaranteed access to credit at concessional rates of interest. The Asian miracle is a 'trade-plus' story.

But such a development strategy is now at risk. Many of the world's poorest countries have seen their terms of trade collapse amid the COVID-19 crisis. Protectionism is rife, not just in the battle between the United States and China but because there are also increasing pressures to bring production back to domestic sources to ensure security of supply. These incentives for enhancing domestic production are likely to provide shelter to a much more protectionist approach to trade policy. The openness of international trade is now under global threat.

Furthermore, it is particularly challenging for countries to pursue this openness when the new issues requiring attention are in the services sector, where policy requirements are more complicated than simply a need to reduce tariffs. There are issues concerning regulatory standards that are difficult to negotiate internationally, and high-tech sectors 
are monopolistic and often receive government-funded research support. This can make competition seem unfair, which it often is. The prospect of a battle over cooperation in the development of technology is looming large in the China-US struggle.

Nevertheless, the further freeing up of trade remains vital, as all stand to benefit.

The Indonesian proposals for WTO reform are an important item for the G20 agenda, particularly the proposals to preserve the important dispute-settlement procedure which has been attacked by the United States. Implementation of Asia's flagship trade agreement, the Regional Comprehensive Economic Partnership (RCEP), will be vital. It will run in parallel with whatever the G20 and the WTO agree to do on trade.

It is possible that, just as the moves by the United States, Canada and Mexico towards the North American Free Trade Agreement in the early 1990s helped to push the world towards the signing of the Uruguay Round of trade negotiations, moves towards the implementation of RCEP may once again push the world towards more positive developments in international opening and cooperation.

Climate change issues present a huge global opportunity. Massive plans in the United States and elsewhere are already in place to spearhead global recovery from the COVID-19 crisis by investment in green technology and renewable power generation. The Biden administration will ensure the United States rejoins the Paris Climate Agreement, and the COP26 UN climate change conference in Glasgow in November 2021 provides an opportunity to take that Agreement forward.

Now is the time for governments to show leadership in reforming the global system, a system that is weakened when governments show a preference for short-term bilateral band-aids over long-term multilateral solutions. If Asian countries want a multilateral system to survive, they must promote, use and improve it.

Global alliances are needed to make this happen.

First, the position of the United States is likely to change. The liberal global order and the institutions that have supported it-the IMF, World Bank, the GATT (now WTO) and the UN agencies-were created with the support and leadership of the United States. That order has been under attack for the past four years. The United States has shelved the WTO dispute-settlement process, shown contempt for trade rules and trade partners, withdrawn from the Paris Agreement and cut funding to the WHO. China has responded with its own form of managed trade and state support which flouts WTO rules. We should hope that this behaviour will be reversed and that the United States will once again embrace multilateralism.

The position of China will be critical. China, today's rising

Importantly, the freedom

for countries to act

according to their own objectives must be preserved in the new order that is emerging hegemon, needs to be constrained in the same way that the United States was constrained after 1945 . Like the Marshall Plan, the Belt and Road Initiative must enable multilateral cooperation, rather than-as some fear-a development process distorted towards China's needs. The regional institutions of RCEP may help in managing this process, paying special attention to the role of Chinese stateowned enterprises and to intellectual property issues.

The position of Germany will also be crucial, and the position of the European Union, which Germany leads. So far European imagination has been almost entirely inward-looking in terms of both macroeconomics and trade. But this needs to change.

Until recently, many have hoped that leadership might come from a proactive, global United Kingdom once it had resolved its divorce with the European Union. The United Kingdom wants, and needs, to push for the loosening of trade restrictions in difficult sectors-technology, health and finance-and for climatefriendly reform of international regulatory processes. But meanwhile, the United Kingdom is also trying to extricate itself from its Brexit mess, even going so far as threatening to breach international law as part of its negotiations. Britain is also trying to achieve the impossible task of negotiating a satisfactory free trade agreement with the United States. Unfortunately, as a result of all this, it seems likely that the United Kingdom will continue to retreat from globalisation and that it will carry much less global weight than previously. Still, one exception to this direction of development will be the COP26 conference in Glasgow next November. That might turn out to be a very important gathering, one that has 


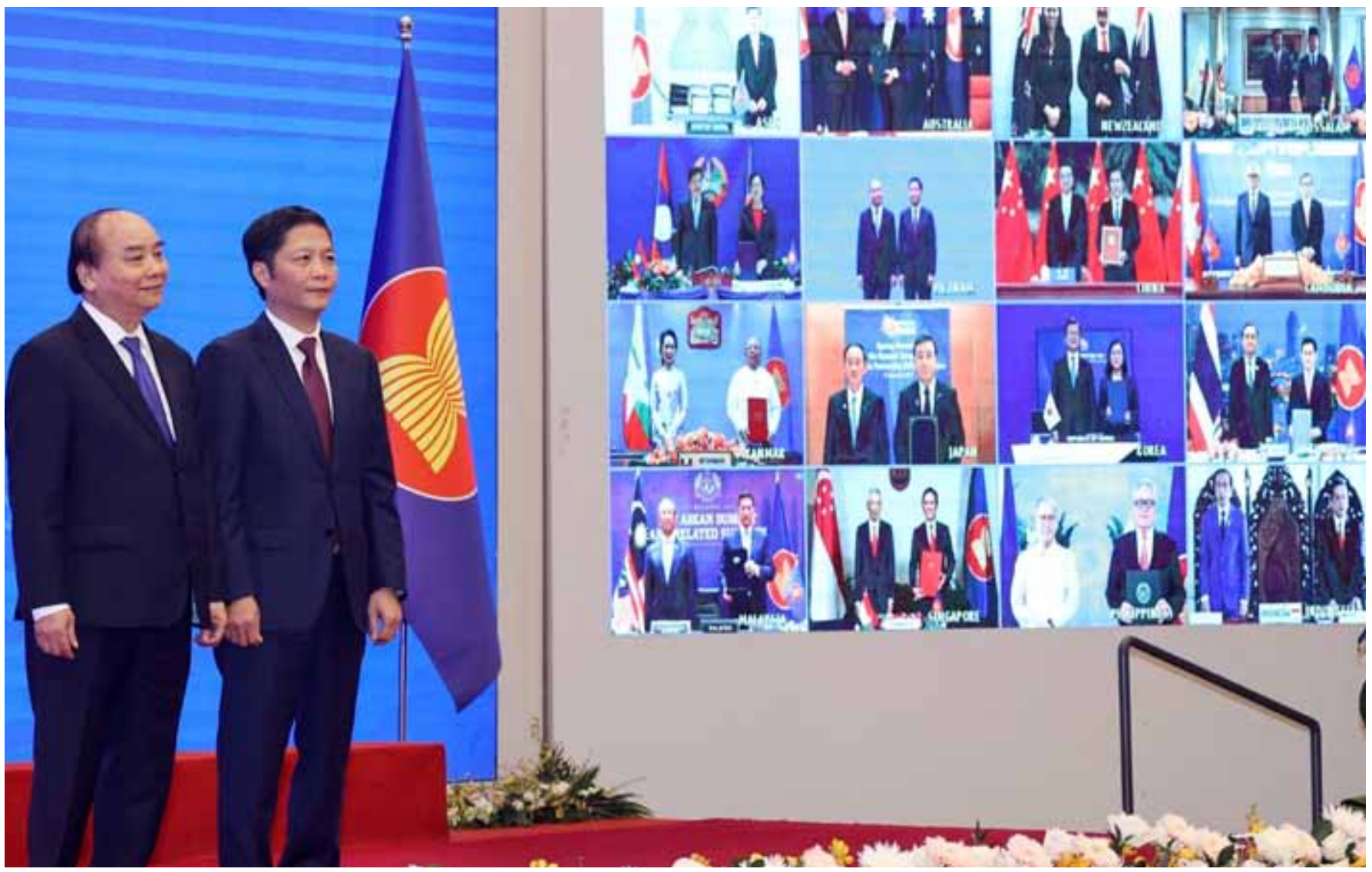

Vietnam's Prime Minister, Nguyen Xuan Phuc, left, at the signing ceremony of the Regional Comprehensive Economic Association (RCEP) on 15 November, 2020.

implications going well beyond climate change issues.

The global order is now more complex than it was immediately after the Second World War when the United States was in a position to lead. Global power is now in the hands of a few dominant countries, rather than one hegemon. A multilateral global order is always important in creating a framework that restrains a hegemon. Now with more than one aspiring hegemon, the task is all the more urgent-and difficult. In the postTrump world, the multilateral world needs to be one that puts restraints on all of the United States, Germany and China.

Asia's experience over the last three decades shows what kind of leadership is necessary in these circumstances. International institutions must be underpinned by trust and voluntary cooperation, rather than through conditionality and enforcement that is imposed by a hegemon. Importantly, the freedom for countries to act according to their own objectives must be preserved in the new order that is emerging. If this is achieved, then it will be possible for domestically-led, behind-the-border reform to go hand-in-hand with international opening and cooperation.

For that to happen, international institutions need to become platforms where information is exchanged, preferences are articulated and compromises are reached-but in which countries remain able to act autonomously. The new institutions which are being created within Asia through the RCEP process will play an important role in this global process.
Indeed, the establishment of RCEP will give Asia the chance to show how cooperation should be promoted and the multilateral order developed, at the global level. This might help prevent conflict between China (the rising superpower), the United States (the previous hegemon) and Germany (the leader of many European nations). The aim must be an international coalition that enables countries to communicate and exchange information, to manage the global macroeconomic system, to continue liberalising international trade, and to build a more climatefriendly world. And they must go on being able to do this, even when tensions emerge. EAFQ

David Vines is an Emeritus Professor of Economics, and Emeritus Fellow of Balliol College, at Oxford University. 


\section{How COVID-19 infected human rights protection}

CHAMPA PATEL

S OUTHEAST Asia already had a poor human rights record before the COVID-19 outbreak. Despite ASEAN's rhetoric on democratic values and human rights, illiberal democracies have been on the rise, putting fundamental freedoms in the region under pressure. Philippine President Rodrigo Duterte continues his 'war on drugs', and the situation of the Rohingya in Myanmar remains unresolved. Cambodia has intensified its restrictions on civil and political rights while Indonesia continues to see democratic backsliding and curtailed freedom of expression, association and assembly. Most countries across the region continue to criminalise dissent using draconian, often colonial-era, laws or new repressive legislation.

COVID-19 has intensified these trends.

Legal controls have been used to repress, silence and undermine human rights during the pandemic. International standards require that restrictions on public health grounds must be enacted with clear objectives and be proportionate, non-discriminatory and limited in duration, yet many Southeast Asian governments have passed emergency measures with no sunset clauses, and with vague provisions allowing for excessive interpretation. Leaders are increasingly using emergency powers to bypass the usual checks and balances, reducing opportunity for scrutiny of new measures.
In the Philippines, President Duterte passed Proclamation No. 922, stating that the public health emergency measures are to remain in force until lifted or withdrawn by his office. He also deployed police and military forces to enforce emergency measures, issuing the military with shoot-to-kill orders against those violating lockdown rules. This approach is not an aberration. Many other countries in the region are also combining legal repression with securitised approaches, going beyond what is proportionate and necessary.

Human Rights Watch has documented extensive human rights violations by Philippine police. This includes confining young children in dog cages and forcing them to sit under the midday sun for hours, among other indignities. These measures are also used to target activists and political opponents. Former congressman Ariel Casilao

Political opportunism has

worrying implications as

authoritarian leaders and

parties seek to extend, deepen and consolidate

their power and other volunteers were about to deliver COVID-19 food aid when they were arrested. The police and local government argued that the volunteers had 'anti-government propaganda materials' in their possession.

Other countries in the region have passed a range of laws that restrict freedom of information, expression and assembly. Thailand declared a state of emergency from late March to late April 2020. The military government exercised special powers that included prohibitions on movement and assembly and restricted the free flow of information. These measures were often counterproductive to combatting COVID-19. In Bangkok, people were arrested for trying to distribute food and sanitisers.

Some countries in the region did not enact new measures but simply deployed existing repressive laws. Indonesia's 2008 Law on Electronic Information and Transactions enabled the government to extensively censor online content. Such laws have led to ludicrous cases that go beyond proportionate measures. A journalist in Cambodia was arrested for quoting verbatim comments about COVID-19 made by Prime Minister Hun Sen. In Myanmar, street artists have been arrested for painting murals of the disease and its impact on society.

Governments in the region have targeted those critical of their responses in the guise of controlling 'fake news'. In Vietnam, several hundred people faced fines for critical content on Facebook, with authorities 


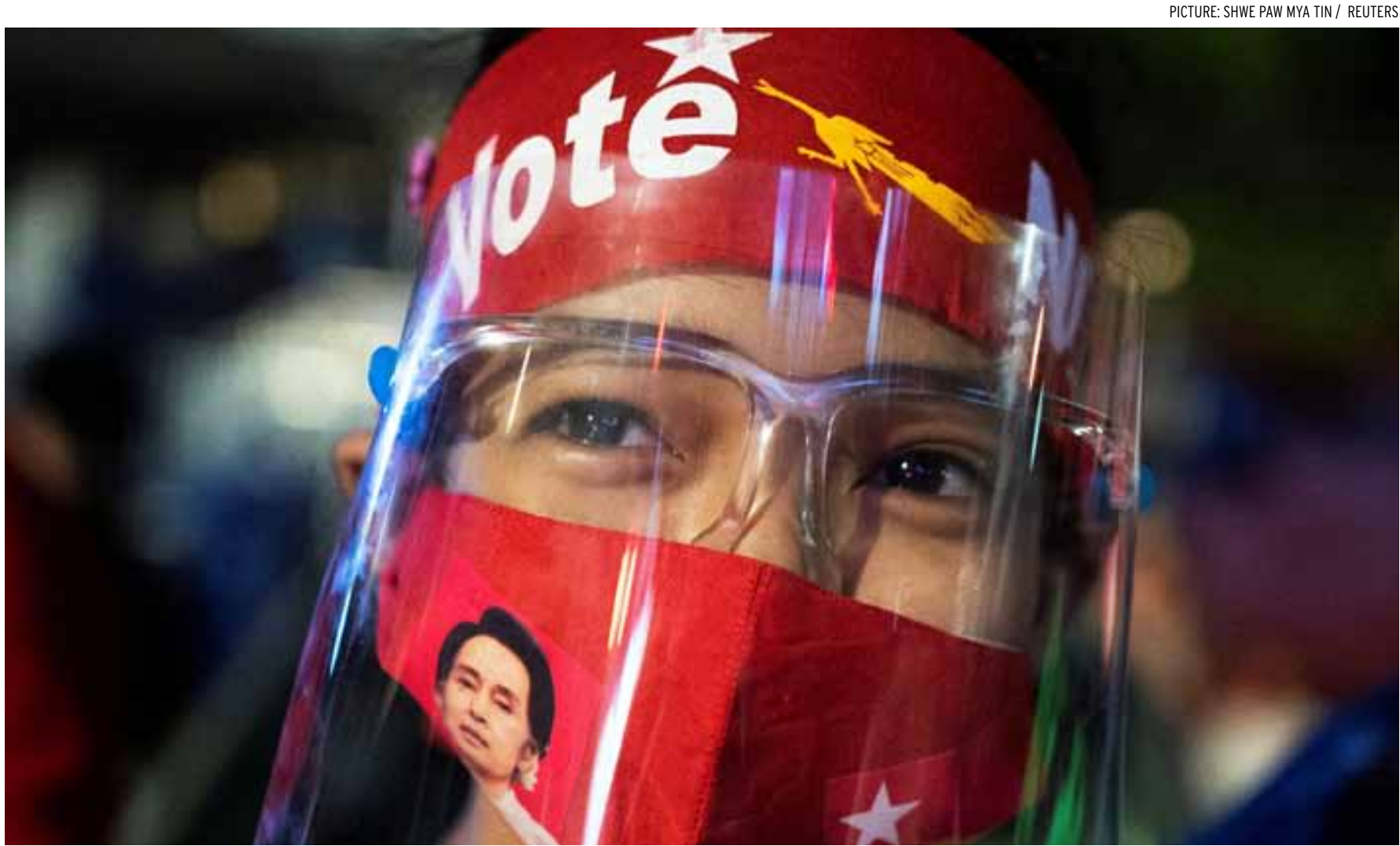

A National League for Democracy supporter awaits results in Yangon after Myanmar's election. Fundamental freedoms in the region are under pressure.

slowing access to the platform for seven weeks until Facebook agreed to block anti-government content to its users. In Indonesia, individuals have been arrested under various communication laws for criticising the government's response.

Another tactic deployed has been restricting access to the internet. Myanmar's internet shutdown greatly impacted an estimated 1.4 million people across Rakhine and Chin states, preventing local populations from accessing necessary information about the pandemic. This is a broader global trend. David Kaye, the UN Special Rapporteur on the promotion and protection of the right to freedom of opinion and expression, voiced his concerns in a report to the Human Rights Council in June 2020, saying that some efforts to combat COVID-19 may be failing to meet the standards of legality, necessity and proportionality.

Emergency measures to combat COVID-19 have also raised concerns about data harvesting, surveillance and privacy. Privacy protections in Singapore were already limited, and now there is further concern that data harvesting of citizens' personal information for health purposes could be used for wider surveillance. Lazarus Chok notes that in countries like Singapore with a strong tradition of state surveillance, 'the dichotomy of public health versus personal privacy has been falsely constructed to justify exceptionally intrusive measures'.

Risk consultancy Verisk Maplecroft's Right to Privacy Index shows that Asia was one of the world's highest risk regions, with COVID-19 surveillance measures further restricting privacy rights. There is a risk that 'unchecked measures' taken during the pandemic could 'become permanent fixtures. The index identifies Cambodia, Thailand and the Philippines as countries within the region that have problematic surveillance measures.

Political opportunism has worrying implications as authoritarian leaders and parties seek to extend, deepen and consolidate their power. Malaysia already struggled to chart a political course following the dissolution of the ruling Pakatan Harapan coalition before the pandemic. In November 2020, two ministers told the Malaysian parliament they were looking to suspend elections. Meanwhile, Singapore's ruling party - the People's Action Partywas criticised for holding an election during the pandemic to maintain its grip on power. However, there are no guarantees that such tactics will work: in the Singaporean case, the opposition party made limited but 
historic gains.

Another trend in the region has been the stigmatisation and discrimination faced by vulnerable and marginalised groups, and the failure to respect and protect their human rights. In March 2020, a Cambodian Ministry of Health report identified Khmer Islam and other groups as having contracted COVID-19, leading to discrimination against the minority Muslim community.

Governments in the region have also adopted securitised approaches to refugees and asylum seekers. For instance, Malaysia has long received Rohingya refugees, yet has engaged in pushbacks at sea, placed refugees in detention camps and targeted journalists who reported on such measures. Existing xenophobic and discriminatory attitudes towards the Rohingya have hardened during the pandemic, with the government enjoying widespread support for its measures.

Even seemingly positive measures to fight the COVID-19 pandemic have often neglected refugees and asylum seekers. Thailand announced a stimulus package for those in the informal sector but recipients must hold a Thai identity card. This effectively excludes most refugees and asylum seekers. These measures also make it difficult to support such communities, as refugees fear arrest, intimidation and discrimination, preventing them from accessing much-needed health services.

That existing discriminatory attitudes prevalent in wider society have sharpened during the pandemic is also evident in the treatment of migrants across the region. Although initially lauded for its pandemic response, Singapore completely overlooked the situation faced by migrant communities. As the number of COVID-19 cases rose within the migrant worker community, there was an upswell of negative commentary on social media. As one activist noted, there was a sense amongst some Singaporeans that 'they're driving our numbers up and it makes us look bad on the world stage, and they should go home'. In Malaysia, a senior minister announced that migrant workers stranded in accommodation-largely people from Bangladesh, India and Pakistan-were the responsibility of their foreign missions rather than the Malaysian government.

All these measures have impacted what was already a shrinking space for civil society organisations (CSOs). Restrictions on movement to prevent the spread of the virus have not made provisions to recognise the role that CSOs play in delivering essential services and supporting community level responses. Thousands of CSOs across the region have tried to ensure that the healthcare, social and welfare needs of the most vulnerable and marginalised were met under restrictive conditions.

As funding, resources and attention are diverted to the pandemic, democracy and human rights CSOs face financial challenges. They have also been targeted for their advocacy work-the Acting Director of the Cambodian League for the Promotion and Defense of Human Rights was

The protection of human

rights is essential to

open, free and

accountable societies threatened because he criticised the authorities' response to the pandemic.

Lockdowns and bans on public assembly also stifled peaceful dissent. Limits on gatherings should be proportionate to the objectives of the health crisis response. Many countries in the region enacted absolute bans on assembly, not allowing for any socially distanced peaceful protests. Such measures have been used to target opposition and critical voices, activists and other marginalised groups.

Despite this, there has been incredible pushback, most notably in Thailand, with democracy protesters calling for human rights to be respected and protected.

Democracy protests have resonated beyond Southeast Asia. The 'Milk Tea Alliance' has brought together activists and protestors from across Thailand, Hong Kong and Taiwan who are fighting for democratic freedoms and accountability. Governments' heavyhanded tactics have not completely quelled citizens' demands for more effective and accountable governance.

The protection of human rights is essential to open, free and accountable societies. COVID-19 has accelerated and intensified repressive trends that threaten human rights. These fault lines existed before the pandemic but have deepened as governments deploy a multiplicity of measures that undermine human rights protection.

Robust pushback against measures that jeopardise democracy, good governance and human rights is critical as governments shift their attention from pandemic management to economic recovery. Trends in the region suggest an uphill battle ahead. EAFQ

Champa Patel is Director of the Asia Pacific Programme at Chatham House, London. 


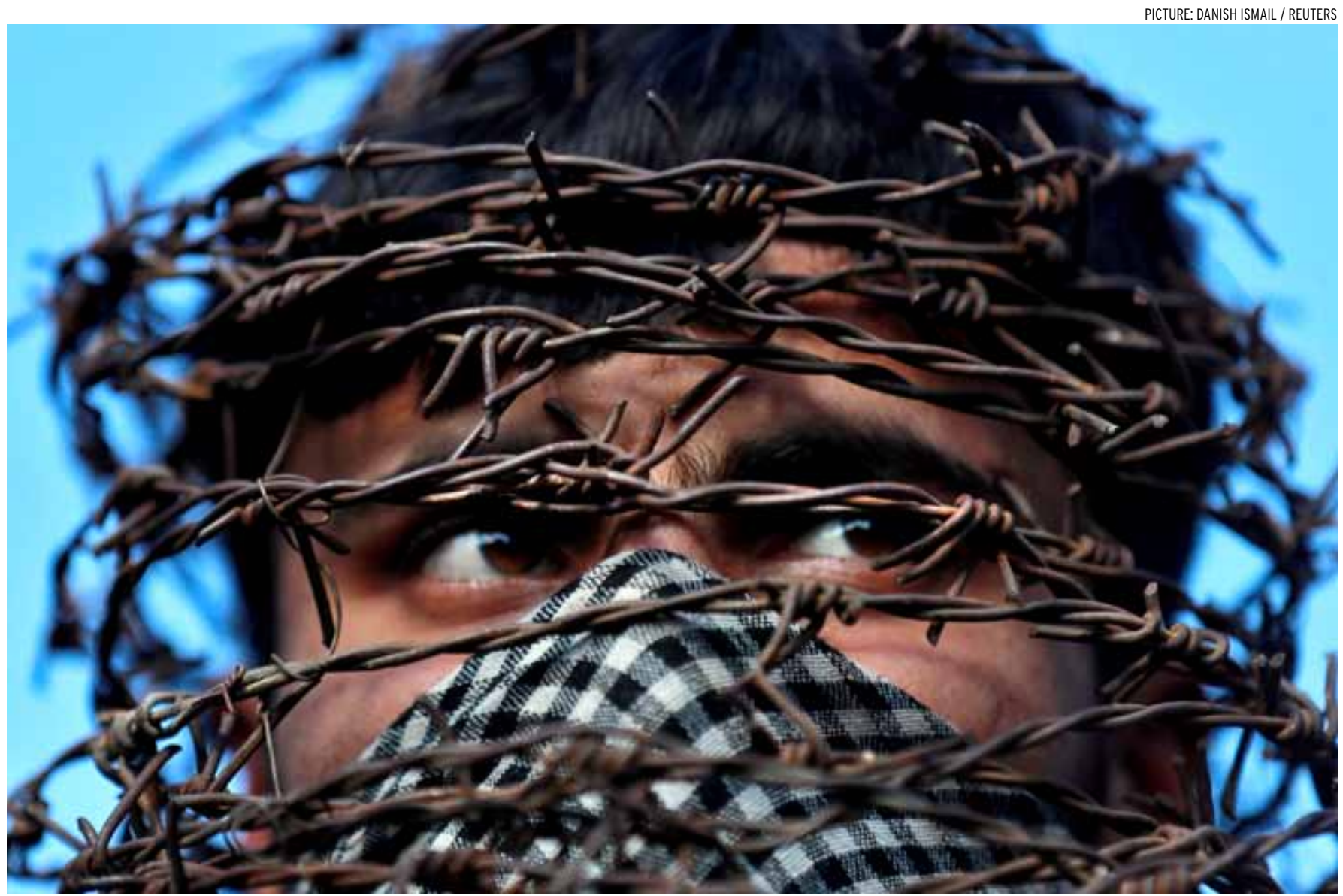

How prison feels: this Kashmiri man wrapped his head with barbed wire in a protest in Srinagar at the scrapping of Kashmir's special constitutional status.

\section{Kashmir still roiled in conflict}

\section{AYESHA RAY}

LOSE to a year-and-a-half since $\checkmark$ the revocation of Kashmir's autonomy on 5 August 2019, the imprisonment of its leaders and youth, and reports of torture by security forces, India continues to smother Kashmir under repression. Severe restrictions during the COVID-19 pandemic-including the termination of internet and communicationsdisplayed disregard for basic humanity by the world's largest democracy.
Although the government has released a significant number of Kashmiris, 400 remain in custody under the Public Safety Act that allows individuals to be detained for two years without trial. Kashmiri journalists who are critical of the government's clampdown on freedom of speech and movement are routinely detained, harassed and silenced in what is a chapter straight out of an authoritarian playbook.

The revocation of Article 370 of the Indian constitution, which allowed
Kashmir a degree of autonomy, was perhaps the Indian government's most undemocratic move against Kashmiris. The decision was made overnight, without consultation or political engagement with Kashmir's various political entities. Feelings of betrayal and alienation now run deep among Kashmiris, who find no reason to place their trust in the central government.

The government's declaration of Union territory status for Ladakh was another unilateral step taken without consultation of its residents. An 
increasing number of people in Leh are now echoing the fears expressed in Kargil in August 2019 about political representation, safeguards for land ownership, job security, domicile status, and protection under Schedule Six of the Indian constitution.

Fears of wholesale demographic change are not unfounded.

Under a new policy called the J\&K Development Act, the term 'permanent resident' has been omitted. This would essentially allow outsiders to invest in Kashmir. As of September 2020 , over 1.6 million residency certificates had been issued across the districts of Jammu and Kashmir. And under a new vague clause in the same act, corps commanders have been given special powers to declare an area 'strategic' for operational and training requirements. The rationale for declaring these areas strategic is unclear. For a state that aspires to live free of Indian military presence, these developments are cause for deep suspicion.

Numerous international organisations have condemned the Indian state's brutalisation of the Kashmiri population. The South Asia director at Human Rights Watch, Meenakshi Ganguly, noted that, despite the government's purported intentions to improve Kashmiri lives, 'the authorities instead have maintained stifling restraints on Kashmiris in violation of their basic rights'.

The Modi government has been quick to silence criticism, forcing organisations like Amnesty International India to shut down operations in the country. In September 2020 India's Enforcement Directorate froze Amnesty's financial accounts after the group published reports critical of the government's human rights record. Contrary to the
Modi government's promise of peace, prosperity and development-made in justification of revoking Kashmir's autonomy-the reality presents an abnormal picture of denial, despair, absence of political engagement and a crippled economy.

After more than 14 months of illegal detention and confinement in their homes, some of Kashmir's mainstream political leaders were released. Their release introduces new complexities in an altered political landscape. The central government in Delhi alienated most of these leaders after stripping the state of its autonomy. New alliances and political partnerships are emerging, many of which are united in their efforts to reinstate Article 370 and statehood for Kashmiris. There are others who are creating their own individual spaces in electoral politics, with a few maintaining their allegiance to the Congress or Bharatiya Janata Party (BJP).

On 24 October 2020, seven mainstream political parties came together to elect the National Conference's Farooq Abdullah as its Chairman and People's Democratic Party (PDP) Chief, and Mehbooba Mufti as its Vice Chairman. Sajjad Lone of the People's Conference is the primary spokesman for the group. This alliance offers a formal structure for the Gupkar Declaration-forged by the political parties in October

Pro-India politicians risked

everything to uphold the Indian constitution during the prolonged 30-year insurgency 2019-that seeks complete restoration of Article 370. Abdullah has argued that the alliance is not running on an anti-national platform despite the BJP's attempts to paint them as treasonous. Both Abdullah and Mufti are former Chief Ministers of the state and erstwhile rivals.

The Jammu Muslim Front (JMF), a separate political bloc, has backed the decision of these parties to unite and fight for the restoration of their status and rights. A spokesman said that the JMF stands for the reinstatement of the rights of all residents of $\mathrm{J}$ and $\mathrm{K}$ irrespective of any discrimination'. In what is being hailed as an important development, these parties with allies on the Left have decided to contest the upcoming elections for District Development Councils and vacant seats of village councils (panchayats) together.

The Modi government's betrayal of Kashmiris has hit pro-India politicians especially hard. Waheed Para from the PDP, which produced the region's last two chief ministers, believes that New Delhi's military intervention on 5 August 2019 is no solution for Kashmir. 'Our disappointment and regret is that we promised things to people which [have been] taken away', he said. 'We promised constitutional spaces to the youth of Kashmir, we promised a solution within the constitution, and these were not only challenged by people or militants but by the government itself'.

Pro-India politicians risked everything to uphold the Indian constitution during the prolonged 30-year insurgency that has painted the valley in violence. Shah Faesal, a popular youth leader from Kashmir, has been silenced since his release. Faesal's father was killed by militants when he was a young boy, turning him towards India. 


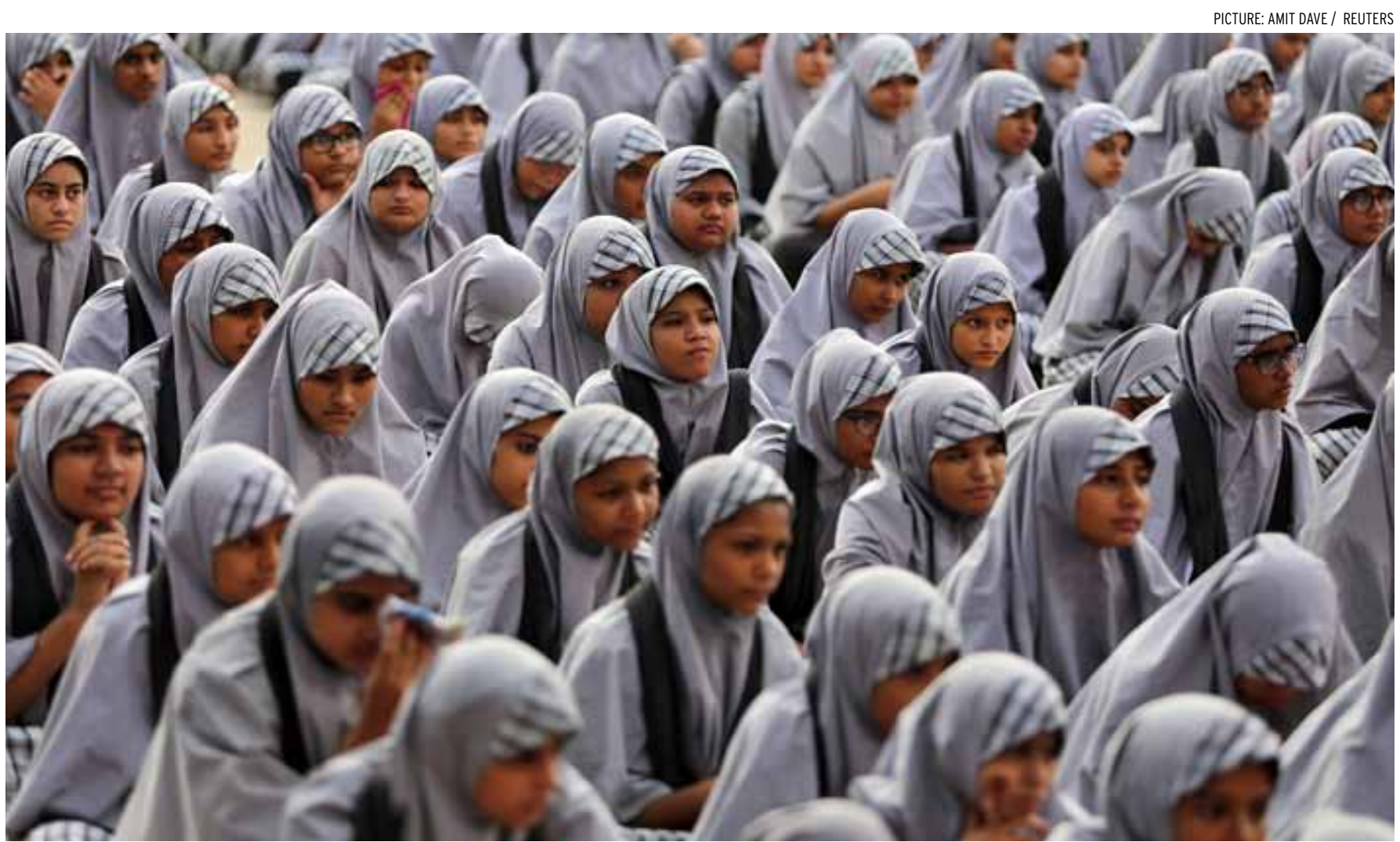

Schoolgirls in Ahmedabad listen to a lecture on Article 370 at an assembly in September 2019 to mark Indian Prime Minister Narendra Modi's birthday.

New Delhi has managed the remarkable feat of alienating proIndia Kashmiri Muslims. The sense of betrayal among these Kashmiris means that the political future and landscape of the region appears uncertain.

The two political constituenciesthat either seek a merger with Pakistan or complete independence from both countries-remain important political forces in the valley. They were always deeply disenchanted with mainstream leaders, often seeing them as wilful participants in maintaining the status quo or accomplices in the Indian state's project to integrate Kashmir with India. Mainstream leaders have been browbeaten into silence by both Indian and Kashmiri nationalists.

A significant majority of Kashmiri Muslims who aspire to independence do not accept the 1947 Instrument of Accession that established Kashmir's legal and constitutional link to India.
This group is less concerned with questions of autonomy and more with the promise of a plebiscite that was never held.

Three external states wielding influence on Kashmir in international diplomacy are Pakistan, China and peripherally, the United States. India's actions in Kashmir have evoked strong reactions from all three. This could mean greater friction in Indian foreign policy.

The continued COVID-19 lockdown in Kashmir gave a tremendous boost to Pakistan's confidence. In the aftermath of the lockdown, Pakistan's Prime Minister, Imran Khan, raised the issue at the United Nations, urging the international community to take serious note of the India's military siege of Kashmir. Senior officials in his administration ramped up the rhetoric, claiming most of Kashmir, despite its disputed nature. The Pakistani state has since taken a number of steps to establish greater influence and control over the region.

Pakistan officially inaugurated the Kashmir Highway as Srinagar Highway on 5 August 2020. Srinagar is the capital of Indian administered Kashmir. Imran Khan pledged to declare the area of Gilgit-Baltistanwhich is part of Pakistani-ruled Kashmir-the fifth province of Pakistan and gave it provisional status. While Islamabad lays claim to the entire Kashmir region, including Indian-controlled Kashmir, New Delhi considers Pakistan-controlled Kashmir (Azad Kashmir), as well as Gilgit-Baltistan, to be Indian territory. Pakistan's intention to declare GilgitBaltistan its fifth province is being denounced by Kashmiri nationalists seeking an independent state.

Further steps to change the status 
of Kashmir are likely to heighten tensions between India and Pakistan and be detrimental to the long-term security of both Kashmiri and Indian civilians. Both countries will find it extremely hard to reconcile their divergent positions in the interests of the Kashmiri population at large. Kashmir will continue to suffer, caught between India and Pakistan's territorial and geopolitical wars.

Pakistan's strategic alliance with China should give some pause to policymakers in New Delhi. After India stripped Kashmir of autonomy in August 2019, China came out openly in support of Pakistan. In a statement, Chinese President Xi Jinping supported Pakistan's safeguarding of its rights and hoped that the dispute would be resolved through peaceful dialogue.

China and Pakistan also share a deep strategic interest in the ChinaPakistan Economic Corridor, a US\$60 billion infrastructure project that China has launched as part of its Belt and Road Initiative. The strong relationship China and Pakistan have forged over Kashmir takes on greater relevance in the context of recent border clashes between China and India in the Galwan and Pangong Tso areas of Ladakh. Experts have cautioned that any escalation of hostilities may end up making India vulnerable to a two-front war in the region, posing dangerous problems for its national security.

In the United States, the prolonged lockdown and military siege of Kashmir attracted condemnation from several human rights activists and lawmakers. Senators Bernie Sanders and Elizabeth Warren, and Congresswoman Pramila Jayapal called for an end to the lockdown and restoration of basic civil rights and liberties. Following the defeat of US
President Donald Trump, all eyes are now set on the new administration's approach to Kashmir.

The Biden administration, while maintaining its strategic, defence and economic partnership with India, seems likely to adopt a more persuasive approach on the subject of human rights-a stark departure from the record of the Trump administration. Official statements on the Biden-Harris Transition Website refer to both Kashmir and the CAA protests. Both incoming US president Joe Biden and vice president Kamala Harris have been strongly critical of the Modi government's human rights record in India and Kashmir.

N HIS Agenda for MuslimAmerican Communities, Biden condemned the Modi government's new citizenship act, calling the project 'inconsistent with the country's long tradition of secularism and with sustaining a multi-ethnic, multireligious democracy'. On Kashmir, the document states that 'the Indian government should take all necessary steps to restore the rights for all the people of Kashmir. Restrictions on dissent, such as preventing peaceful protests or shutting or slowing down the internet, weaken democracy'.

In the time ahead, Pakistan, China and the United States will shape much of the international response to Kashmir.

India's rationale for stripping Kashmir's autonomy was to bring an end to cross-border terrorism and to bring peace to the region. The evidence suggests that the decision to revoke Kashmir's autonomy has made the state far more vulnerable to violence from militant groups.

A growing body of Kashmiris have joined the ranks of militant groups and are engaging Indian security forces in encounters. 2020 witnessed the second-highest recruitment of militants in the last decade. Civilians have also been attacked in multiple grenade attacks. Militants have launched a series of premeditated attacks on local Kashmiri politicians belonging to the BJP and Congress.

A new militant organisation called The Resistance Front (TRF) has emerged, drawing from Lashkar and Hizbul Mujahideen cadres. The TRF has claimed several attacks since the start of 2020-including an attack on Lal Chowk, Srinagar, on 2 February and the killing of five soldiers in Kupwara on 1-4 April. On 3 May, the TRF claimed responsibility for the deaths of five security forces personnel, including an army colonel and a major in an encounter at Handwara in Kupwara. Two days later, three Central Reserve Police Force (CRPF) men were killed when the TRF attacked a CRPF party at Handwara in Kupwara. One mentally disabled boy was also killed in the crossfire.

An intelligence report indicates that TRF is controlled from Pakistan by three top handlers from the Lashkar-e-Taiba-Sajad Jatt for South Kashmir, Khalid for Central Kashmir, and Hanzala Adnan for North Kashmir. The Pakistani state appears to be exploiting the situation to its advantage.

In the absence of political engagement from New Delhi, the future is likely to hold further violence and conflict. This will destroy the lives of ordinary Kashmiris caught in a conflict involving militants and India and Pakistan's competing territorial ambitions. EAFO

Ayesha Ray is Associate Professor in the Department of Political Science at King's College, Pennsylvania, United States of America. 


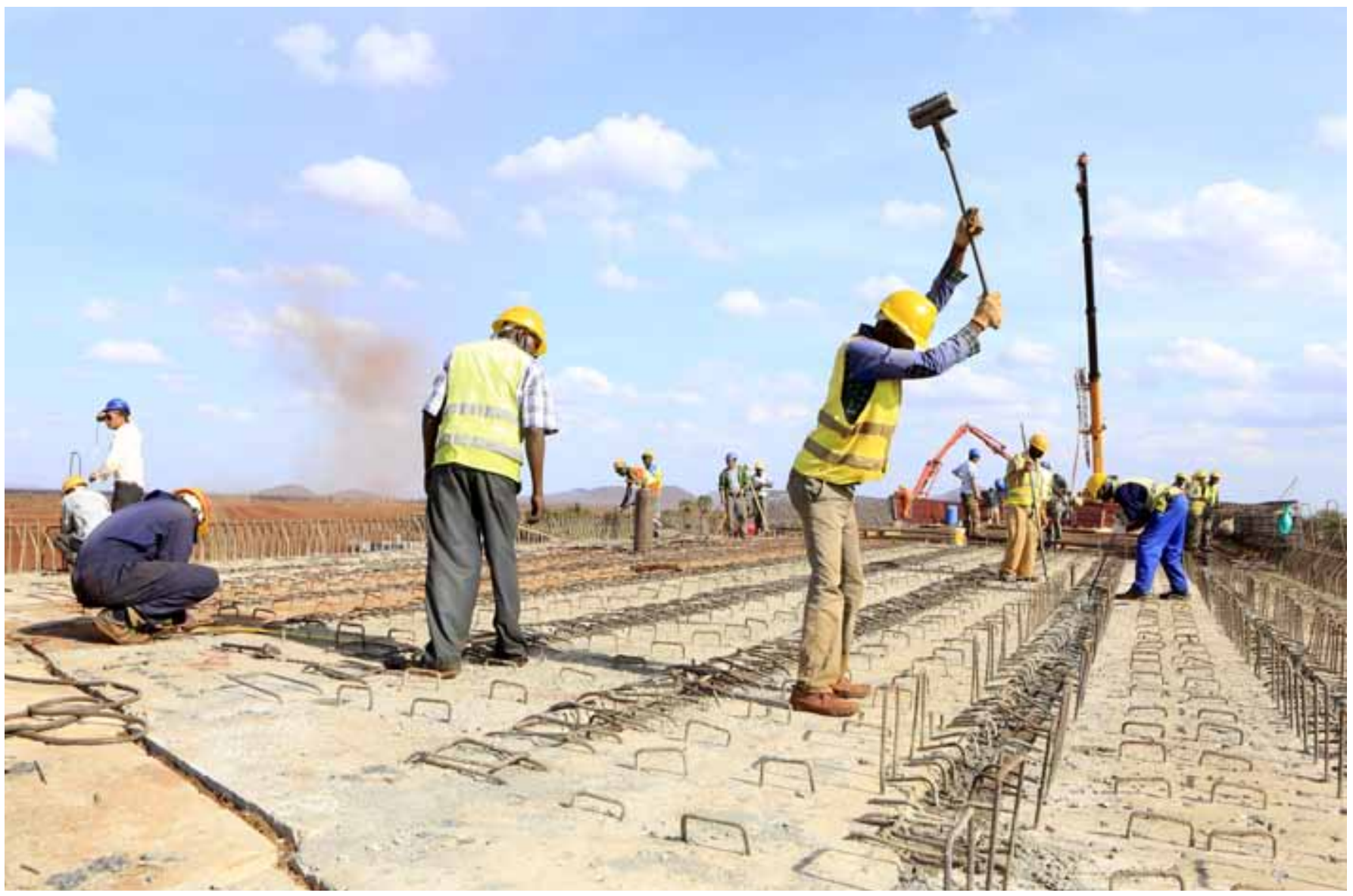

Workers laying track at an overpass bridge at Emali, Kenya, on the Mombasa-Nairobi standard gauge railway. Africa is a focus of BRI activities.

\section{China takes a page from the US Cold War playbook}

\section{WILLIAM H. OVERHOLT}

$\mathbf{T}$ HE Belt and Road Initiative

(BRI) is a branding exercise for China and its leader and a make-work project for state enterprises. It is also a national security strategy that adapts US Cold War policy to China's present circumstance.

In America's Cold War victory there was no grand military battle. The United States created a Washingtoncentred development network that nurtured America and its allies. At its core were the institutions of the Bretton Woods system-a World Bank that funded infrastructure together with the International Monetary Fund (IMF) and General Agreement on Tariffs and Trade (GATT)/World Trade Organization (WTO), which facilitated trade and investment by creating common standards and providing emergency support.

The Bretton Woods system was supported by key domestic institutions: the State Department, USAID, US Information Service (USIS) and a US dollar that provided global liquidity and a common standard of value. This economic strategy was underwritten by military strength, which was necessary but not the key to success.

By contrast, the USSR chose a relatively autarkic economy, predatory relations with allies and overwhelming military priorities. The US system flourished and the USSR bankrupted itself-a US economic victory.

Postwar US allies and adversaries have similarly risen to power through 
an emphasis on domestic and international economic prioritiesnotably Germany, Japan, South Korea, Singapore and Indonesia. Deng Xiaoping cut China's military budget from 16 per cent of GDP to 3 per cent to prioritise economic growth and join the open global system.

After its Cold War victory, a complacent United States allowed the instruments of success to atrophy. Congress repeatedly delayed capital increases for the Bretton Woods institutions. Motivated by dislike for China and other emerging powers, it refused to update governance to reflect the modern global economy. The State Department budget steadily deteriorated. USIS was abolished. USAID dwindled. Democrats and Republicans alike responded to the decline of manufacturing jobs by deflecting the blame to globalisation and China, which were responsible only for about one seventh of the displacement.

The resulting social crisis undermined public support for America's successful strategy and worsened tensions with China. Budgets became driven not by strategy but by campaign contributions to Congress. Defence companies and contractors made particularly large donations, which meant that the military prospered while other domestic institutions atrophied.

The role of the Bretton Woods institutions declined. That created a vacuum, for instance of US $\$ 12$ trillion in needed infrastructure investment in emerging economies. Overuse of US dollar sanctions created a reaction against dollar hegemony.

China has moved in to fill the gap. Its first institutional initiative, the Asia Infrastructure Investment Bank (AIIB), was tailored for consistency with Bretton Woods. Its leader,
Jin Liqun, a veteran of the World Bank and Asian Development Bank (ADB), was driven by determination to create a high-quality institution without the World Bank's sclerosis. Washington responded with an evidence-free theory that the AIIB would institutionalise low lending standards unless blocked. Nevertheless, 102 countries joined and many others collaborate informally. AIIB's subsequent collaboration with the Bretton Woods institutions has justified their decision.

The US decision to inhibit a role for China in the Bretton Woods institutions and elsewhere proportionate to its economy has consistently enhanced China's global role and weakened that of the United States.

The BRI, now the big global game, emulates the Bretton Woods system. It includes development banks to fund infrastructure and systematic efforts to create common standards in railroads, customs clearance procedures, IT standards and much else. It also contains a push for the renminbi to become a global currency, a currency swap system (originally a Japan-

Like Japan in the 1980s, China's success made its developing-country protectionism and technological predation an unacceptable threat to Western businesses
ASEAN initiative) to supplement or replace IMF emergency loans, and institutions to liberalise trade and investment. China is now a leader in trade expansion, green energy and environmental alleviation.

But the BRI has diverged from Chinese leaders' earlier priority for compatibility with Bretton Woods. The global financial crisis convinced Chinese leaders that the Western economic model is prone to catastrophic collapse. Trump and Brexit convinced them that the Western political model is prone to economic mismanagement.

Like Japan in the 1980s, China's success made its developing-country protectionism and technological predation an unacceptable threat to Western businesses. Trump mismanaged the US riposte. Xi Jinping's China has yet, unlike Japan, to abandon developing-country mercantilism while incongruously asserting global leadership.

The BRI is nonetheless an inspiring vision. In Africa, China convenes four dozen heads of state to make development plans, then delivers funding and roads. In contrast, Washington's development program centres on defence. It provides special forces teams to fight terrorism plus an offshore military presence. If that is the game of competition for influence, China wins. The greatest recent source of US influence in Africa was President George W. Bush's HIV initiative. Even on terrorism, the United States wins tactical battles, but BRI successes provide strategic anti-terrorism victories.

The United States has three potential responses to the BRI.

First, it can compete. This is a US game. But Washington's contribution has been a pittance, not the product of a strategy. The United States should 


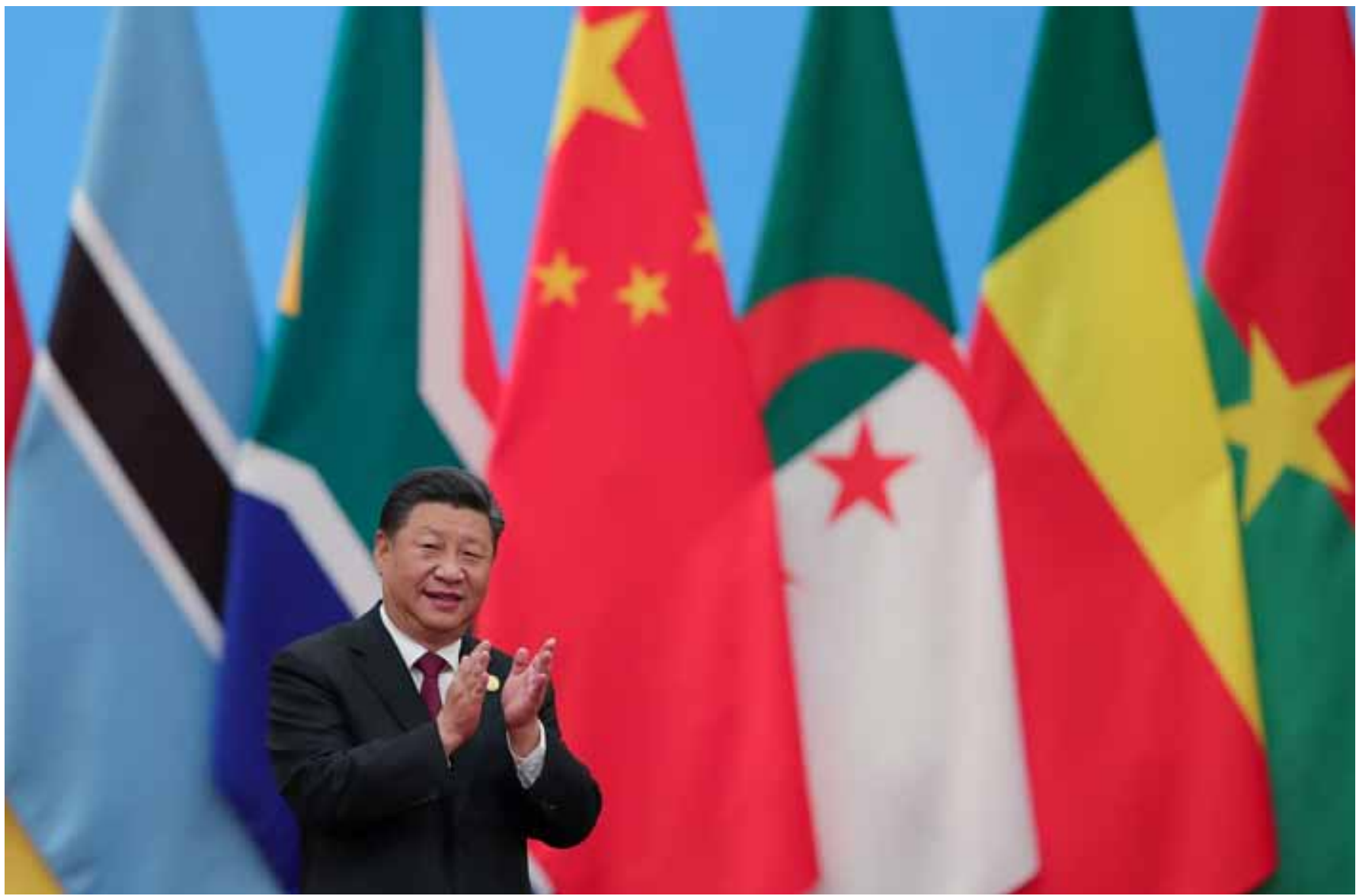

Chinese President Xi Jinping applauds delegates to the 2018 Beijing Summit of the Forum on China-Africa Cooperation Round Table Conference at the Great Hall of the People in Beijing on 4 September, 2018. China has moved to fill the gap as the role of Bretton Woods institutions has declined.

look to countries such as Japan if it wishes to compete successfully. China negotiates a power deal in Indonesia, offering second-rate technology and high prices and demanding a government guarantee. Japan counteroffers with first-rate technology, reasonable prices, demonstrated reliability and feasibility studies that obviate the need for a government guarantee. Japan wins. Indonesia wins.

Second, the United States can compete and co-opt, as it did when it faced economic rivalry with Japan in the 1980s. Japan was competing unfairly in the same ways that China is today: bribes, tied aid, subsidies and cheap interest. By negotiating some common standards, the United
States and Japan both won. Above all, countries like Indonesia won. This is still possible with China, because China faces the same problems of competitiveness, sustainability and creditworthiness that Japan did.

Third, the United States can stand on the sidelines and whine. So far, this has been Washington's main response. For instance, it repeats a discredited assertion that the BRI deliberately seeks to create debt traps for emerging economies.

Often the United States wins even when the BRI succeeds. When successful, systems like Bretton Woods or the BRI stabilise countries, reducing the risk of war or terrorism. In the 1960s, Indonesia had the world's third largest communist party and a significant Islamist movement. With competitive JapanUS help, Indonesian economic growth gave almost everyone a stake in society; the Islamist movement was domesticated into a secular polity and the communist party lacked the social base to revive after the military crushed it. Had Washington instead deployed the military, it would still be fighting and losing.

Likewise, in the 1970s it appeared that Bangladesh was going to be a failed state, probably becoming something like Somalia is today. Instead, the textile industry spilt over from China, employing millions and stabilising the country. While the factories moved from China, the largest ownership of those factories 
was American. Bangladesh's relative stability is a joint China-US national security success.

Not long ago, Ethiopia had six violently contending Leninist parties and a great famine. Until the recent eruption of ethnic strife, it had been the world's fastest-growing country and its politics had become more liberal. The largest foreign contributor to this success is Chinese advice, railroads and factories.

As a rough rule of thumb, each of these successes saves the United States US\$1 trillion in anti-terrorism efforts. Washington needs to compete and collaborate with China to spread such successes. The BRI mostly services the parts of the world least affected by Bretton Woods successes: Central Asia, the Middle East, Africa. Just denouncing it discredits the United States and enhances China's standing.

The outcome of the BRI is unclear. What it means and how it works changes frequently.

In Africa, it is on balance quite successful-globally, 138 countries have formally joined and many others collaborate. But China is discovering that it has finite financial resources. Inattention to creditworthiness has created massive bad debts for China's banks. Most lending has eschewed the AIIB's standards. China's drive for a global currency is running backwards. China's predatory technology policies and protectionism have elicited a growing pushback. The BRI's aspiration to a 'community of common interests' clashes with China's predatory relations with maritime neighbours.

That said, just as Bretton Woods rode and accelerated the wave of western European and eastern Asian recovery from World War II, the $\mathrm{BRI}$ is riding and accelerating this century's great trends-the integration of Eurasia and the emergence of Africa. The BRI's globally networked strategy is far more sophisticated than Bretton Woods' mostly bilateral vision. Recipients are gratified that the BRI builds roads immediately while World Bank bureaucracy often takes eight years to make a decision.

China is playing the right game. The United States is not.

Why is the United States failing to play the right game when its Cold War strategy delivered the most successful geopolitical outcome in world history?

Part of the problem is that scholars have failed to articulate the postwar geoeconomic game. They preoccupy themselves with pre-World War II military conflicts-Athens and Sparta, Germany and Britain-without acknowledging that post-World War II leadership depends on a rebalancing toward economic priorities and a non-zero-sum mentality. But above all, peacetime resources are allocated by congressional lobbying - not by strategy.

While the BRI has profound flaws and contradictions, as long as China has the only modern national strategy of any major power it will continue to make gains at the United States' expense. EAFQ

William H. Overholt is Senior Research Fellow at Harvard's Kennedy School and author of The Rise of China, China's Crisis of Success and America and Asia: The Transformation of Geopolitics (Cambridge University Press, 2008).

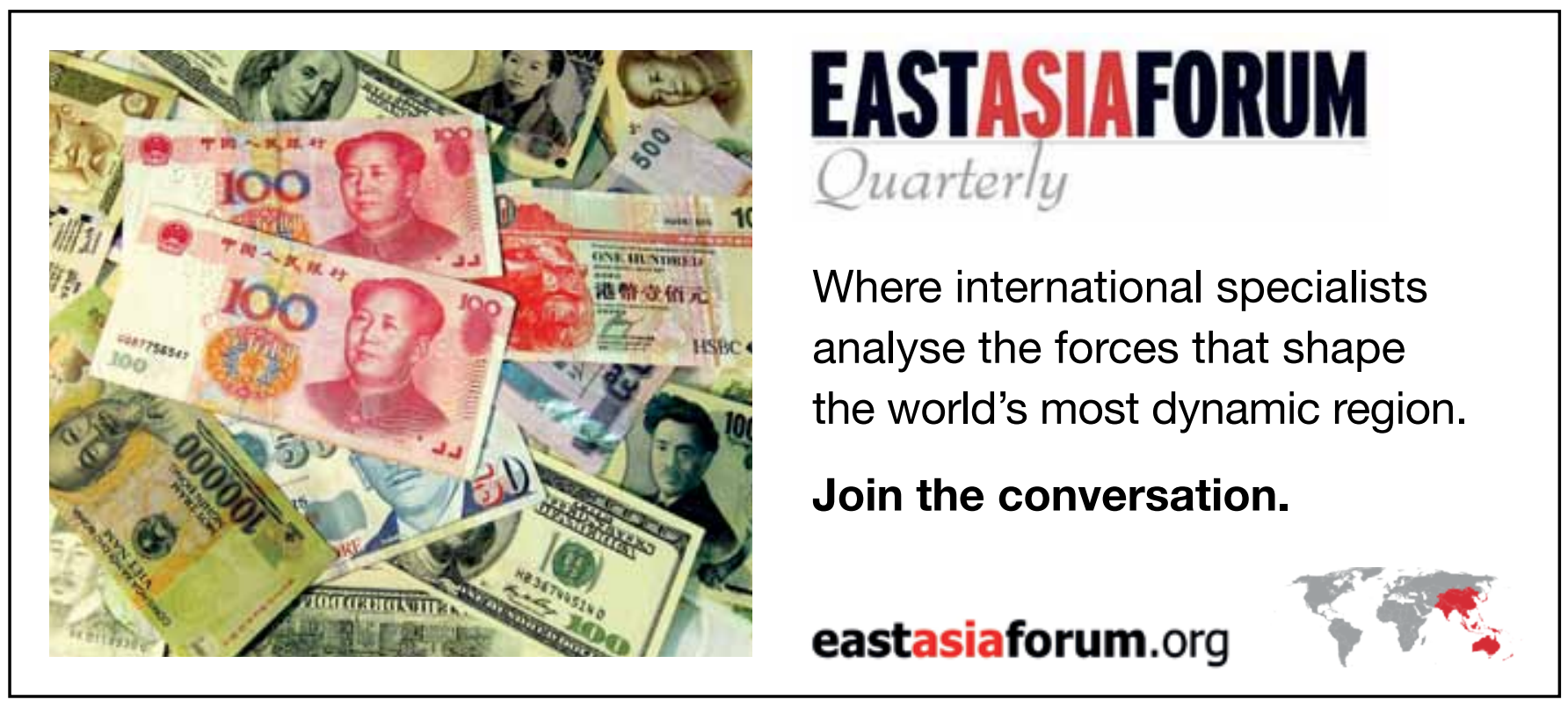


PICTURE: THOMAS PETER/ REUTERS

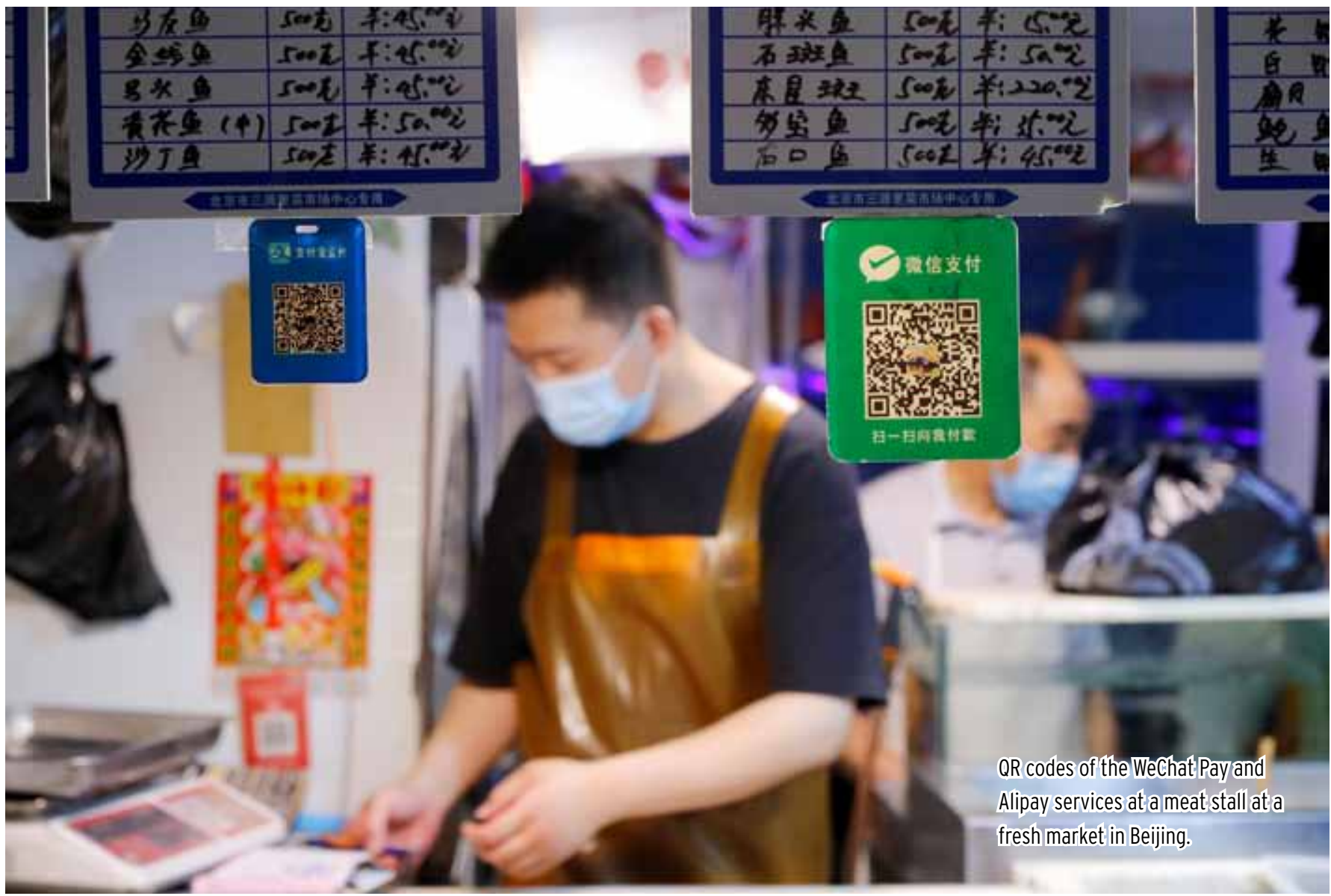

\section{How digital technology is transforming China's economy}

\section{YIPING HUANG}

W HEN COVID-19 hit China in late January 2020, the government implemented aggressive measures such as social distancing and lockdowns to stop the spread of the virus. This led to a dramatic decline in offline economic activities, especially in restaurants, hotels, cinemas, parks and shops. Meanwhile, online economic activities such as e-commerce and online education programs surged. Many restaurants started offering door-to-door delivery services, and the digital economy, taking advantage of its contact-free nature, played an important role as a macroeconomic stabiliser.

This is one example of how digital technology, including 'bigtech' platforms, big data, artificial intelligence (AI) and cloud computing, is transforming the Chinese economy. China's first e-commerce platform, Alibaba's Taobao, was launched in June 2003-the month before the World Health Organization declared the SARS outbreak contained. But e-commerce did not surge until
2013, when smart phones and 3G/4G networks became widely available. Before that, online shopping was built mainly on desktop computers and $2 \mathrm{G}$ wireless networks, making the user experience not particularly enjoyable. By the end of 2019 online shopping had already exceeded one quarter of China's total retail sales.

To facilitate growth in e-commerce, Alibaba had to overcome one major obstacle-online payment. A lack of trust between buyers and sellers made it hard to close online transactions. At the end of 2004 Alibaba launched 
what is now known as Alipay, the world's largest mobile payment service provider. By mid-2019, Alipay had 1.2 billion users.

Alipay's main competitor, WeChat Pay, was launched on that social media platform in 2013. WeChat Pay attracted a large number of users by introducing electronic red envelopes during the Chinese New Year in 2014. By mid-2019, WeChat Pay had about 900 million users.

Mobile payment is by far the most successful financial technology (fintech) product in China. Without it, the digital economic activities that helped to stabilise the macroeconomy during the COVID-19 pandemic would not have occurred. But the most important contribution of mobile payments is financial inclusion, dramatically expanding access to those left out by traditional financial institutions. With a smart phone and telecom signal, one can enjoy payment and other financial services from anywhere. Some studies show that when farmers start using mobile payment services, their job opportunities expand and their income rises.

T ODAY, Alipay and WeChat Pay are no longer just means of payment; they have built comprehensive 'ecosystems' around them. Users can organise their daily lives on these ecosystems-booking hotels, calling taxis, buying plane tickets, ordering food delivery and so on.

Some large tech companies, such as Ant (the fintech arm of Alibaba) and Tencent (the company that created WeChat), started to provide credit by developing a new bigtech credit risk management system. This system contains two pillars: bigtech platforms and big data credit risk assessment.
Chinese bigtech platforms such as Taobao/Alipay and WeChat/WeChat Pay play important roles in three ways. First, they help acquire large numbers of customers at low cost, taking advantage of the platforms' long tail feature. Second, they record customers' digital footprints and accumulate big data for real-time monitoring of the potential borrowers' activities, forming the input for the credit risk analysis. Finally, they may also help with repayment management.

The combination of bigtech platforms and big data credit risk assessment enables bigtech companies to grant credit to large numbers of individuals and small- and mediumsized enterprises (SMEs), most of which have never borrowed from a bank. One bigtech lender, Antaffiliated MYbank, has a '3-1-0' business model: it takes less than three minutes to apply online, if approved, the money is transferred to the applicant's account in one second, and there is zero human intervention.

In this way, each of the three Chinese bigtech lenders can grant more than 10 million loans every year. More importantly, their average nonperforming loan ratio is below 2 per cent, compared with an average of 5.5 per cent for commercial banks' SME loans (loans smaller than 5 million RMB).

Big tech credit was also behind the relatively more stable Chinese economic activity during the COVID-19 crisis. Another important contribution to macroeconomic and financial stability is removing what former US Federal Reserve chairman Ben Bernanke called the 'financial accelerator'. Since most SME loans from commercial banks are collateralised, there is a positive feedback mechanism between property prices and credit policy.

This means that a small drop in property price may end in a financial crisis. The elasticity of collateralised credit by commercial banks with respect to local property prices is about 0.6 , meaning a 10 per cent fall in property values leads to a credit squeeze of 6 per cent. This vulnerability is not shared by fintech firms, which lend based on data rather than collateral. The elasticity of MYbank credit with respect to local property prices is statistically insignificant.

D IGITAL technology is changing the Chinese economy, making it more convenient, increasing efficiency, reducing costs, replacing labour and improving user experience. This is particularly important as China has a rapidly ageing population. In many areas, robots and AI may substitute for labour, helping to ease the labour shortage problem.

But the digital transformation has just started, and it will take time to fully understand its economic consequences. While some of the benefits are obvious, digital technology also creates problems for disadvantaged groups. For instance, there was a widely circulated news story during the COVID-19 pandemic in China of an old man who was stopped from taking the subway when he failed to produce his electronic health code. This is only one example of the potential problems that the government needs to address.

Yiping Huang is a Professor and Deputy Dean at the National School of Development and Director of the Institute of Digital Finance, Peking University. 


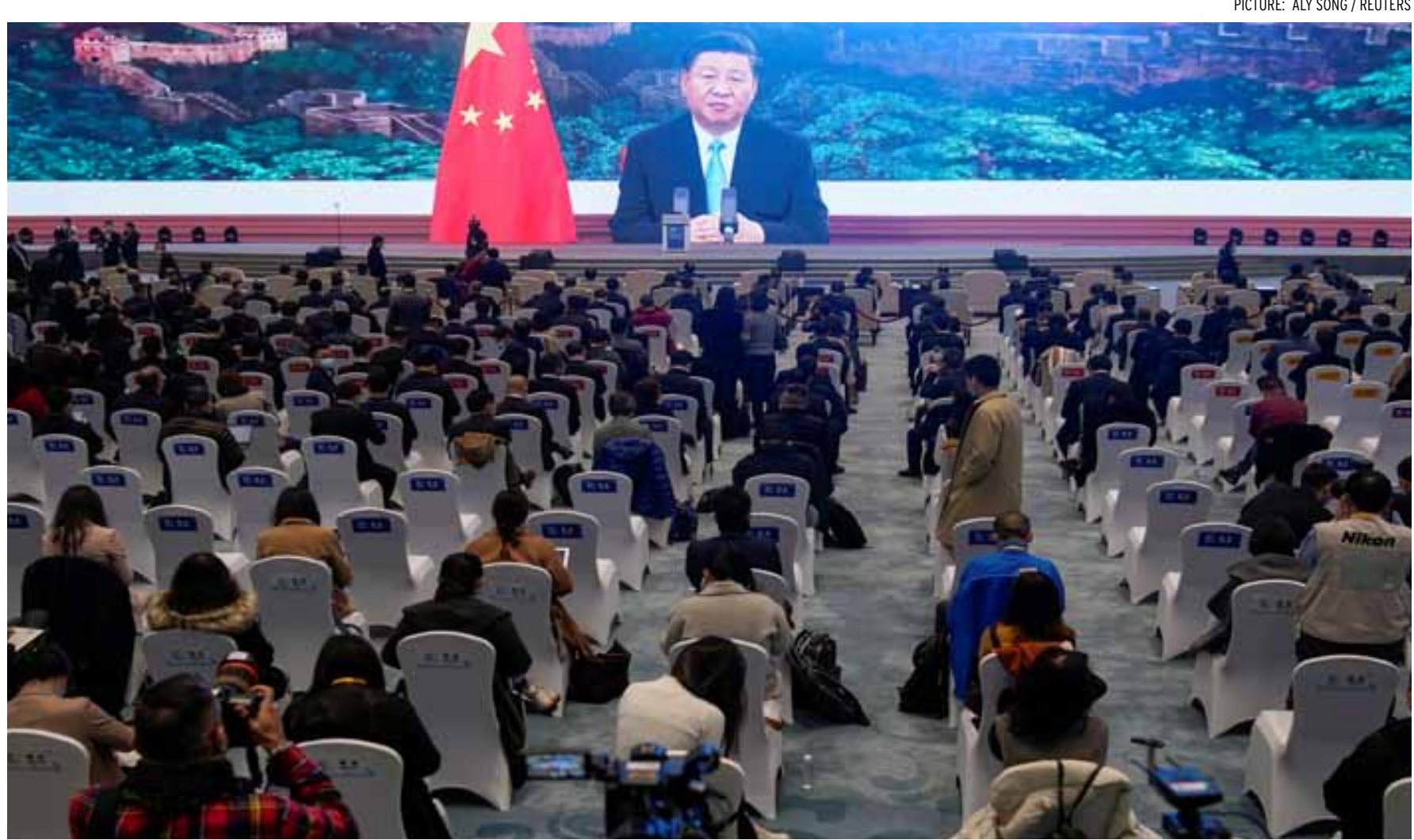

China's President Xi Jinping addresses delegates at the opening ceremony of the World Internet Conference in Wuzhen, Zhejiang province, in November 2020.

\section{Whither China's technology dream?}

\section{ANDREW KENNEDY}

HINA'S dreams of becoming a world leader in science and technology (S\&T) have inspired both admirers and sceptics for years. Today, these dreams seem to be coming true. China has launched manned space flights, sent the world's first quantumcommunications satellite into space, and is leading the world into the $5 \mathrm{G}$ era. But despite these successes, China still struggles in important respects, and the country now faces new challenges that raise questions about its S\&T future.

The extent of China's high-tech ambitions under President Xi Jinping are evident in a series of policy initiatives. Since 2014, dramatic reforms have overhauled the structure of China's science funding system.

In 2015, the Made in China 2025 (MIC2025) program prioritised state support for 10 high-tech sectors and called for 70 per cent self-sufficiency in core components and basic materials by 2025 . In 2017, China unveiled a new initiative to make the country the 'world's primary artificial intelligence innovation centre' by 2030 .

Underpinning all these ambitions is growing investment in technology. By 2018, China's share of world research and development (R\&D) investment stood at 22 per cent-second only to the United States' share, at 25 per cent. China is now expected to take the lead before 2025. Roughly three-quarters of China's R\&D investment comes from business. Still, government officials remain deeply involved in the allocation of capital, not only through state-owned banks but also through a range of other means, including the growing number of governmentguided investment funds, many of which target high-tech firms.

China's growing list of S\&T achievements do not simply reflect the influx of investment. In fact, China's 
performance may be most impressive in basic science, even though China invests less in basic research as a share of national R\&D spending than other science leaders. China's remarkable performance is evident in the Nature Index, which tracks how often scientists from different countries publish in the world's top scientific journals. While the United States still leads the world, China's score in the index has surged from 24 to 67 per cent of the US score since 2012.

China's rise in basic science reflects in part the intense pressure on Chinese scientists to publish top-tier articles within short time horizons, though this also generates a wide range of academic misconduct, including plagiarism and faked peer review. China's performance also reflects the remarkable degree of collaboration between the US and Chinese scientific communities, as reflected in student flows, academic exchanges and collaborative research. China has emerged as far and away the leading source of co-authors for US scientists.

China's performance on the corporate side is more mixed. Huawei's leadership in $5 \mathrm{G}$ is both impressive and well-known, though its hardware reportedly has more vulnerabilities than that of other vendors. Chinese firms also lead the way in some areas of artificial intelligence, such as facial recognition technologies.

China boasts a vibrant start-up scene, with 24 per cent of the world's 'unicorns' (private firms valued at more than US\$1 billion) as of October 2020. China's unicorn share was second only to that of the United States (48 per cent) and far more than the combined shares of India, South Korea and Japan (8 per cent). China's total included the world's two most valuable unicorns-ByteDance and Didi Chuxing.
In other regards, Chinese firms are less impressive. While tech firms are now the world's most valuable companies, China's share of the world's top listed firms has changed little over the past decade. As of 2020, 'Greater China' boasted 14 of the world's top 100 firms by market capitalisation-a modest increase from 11 in 2009. US firms, in contrast, comprised 57 of the top 100. While China did have two firms-Alibaba and Tencent-in the top 10, five of the top six were US tech firms.

China's high-tech ambitions are also facing new challenges under $\mathrm{Xi}$ Jinping. Tighter internet controls, for example, have prompted complaints from elite Chinese scientists about the impact on scientific research. In 2017 the Vice Chair of the Chinese People's Political Consultative Conference, Luo Fuhe, called attention to the problem only to have his remarks censored. The CCP has also tightened its grip on university campuses. In 2016, for example, the party secretary at Tsinghua University said that faculty members' political stances would be given top priority in their performance evaluations.

On the corporate front, Xi generally prioritises China's state-owned sector, even though non-state firms tend to be more dynamic and innovative. While private firms are still valued,

The international

environment is also

becoming much less

friendly to China's S\&T

rise particularly leading tech firms, their proverbial wings have been clipped, as shown in the recent suspension of Ant Group's IPO. More generally, private firms are being forced to accept a greater CCP presence than before and to balance business goals with those of the Party. These measures are likely to further limit the efficiency with which China turns innovation inputs into outputs.

The international environment is also becoming much less friendly to China's S\&T rise. While this is most obvious in the United States, it is increasingly apparent elsewhere as well. With an eye on China, public officials from the European Union to Japan are scrutinising high-tech investments more closely. In October, Sweden became the latest country to ban Huawei from participating in its $5 \mathrm{G}$ networks. India has banned more than 200 mostly Chinese apps, including the video platform TikTok.

The ominous international environment, combined with China's growing high-tech capabilities, is accelerating the country's drive for technological autonomy. In October 2020, Chinese leaders vowed to focus greater efforts on 'scientific and technological self-reliance' following a high-level Party meeting. This commitment must be taken seriously given China's remarkable progress to date. Even so, China's persistent problems coupled with the new challenges it faces mean that success is by no means assured. EAFQ

Andrew Kennedy is Associate Professor in Policy and Governance at the Crawford School of Public Policy, The Australian National University. He is author of The Conflicted Superpower: America's Collaboration with China and India in Global Innovation (Columbia University Press, 2018). 


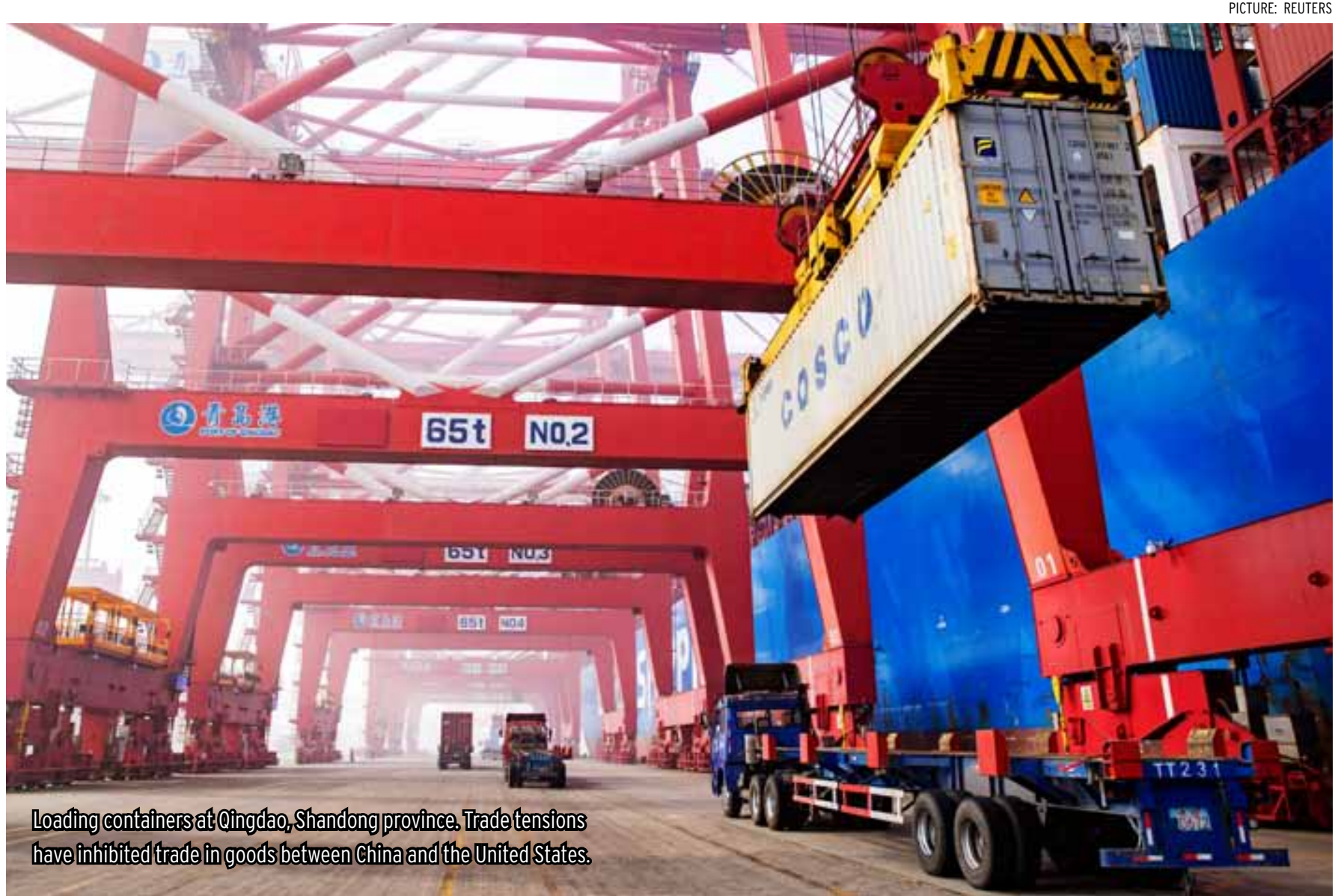

\section{Multilateralism under stress in Sino-US trade conflict}

\section{SONG HONG}

\section{I}

N 2017, the United States Trade Representative (USTR) initiated Section 301 investigations into China's trade practices under the instruction of President Donald Trump. Released in March 2018, the USTR report said that certain Chinese policies, regulations and practices were detrimental to the protection of US intellectual property rights, technological innovation and technological development.

In July 2018 the United States imposed a 25 per cent punitive tariff on US $\$ 50$ billion worth of Chinese imports, most of them high-tech goods. China adopted a tit-for-tat policy, and that resulted in the United States imposing an additional 25 per cent tariff on US $\$ 200$ billion worth of Chinese goods. The following year, China conducted numerous consultations and negotiations with the United States, with both parties finally reaching the phase one trade agreement on 15 January 2020.

According to that agreement, based on 2017 bilateral trade figures, China promised to import an additional
US\$200 billion worth of energy and agricultural products and services from the United States in the following two years.

Along with punitive tariffs came technology sanctions. The United States launched a technology war against China, imposing sanctions on Chinese firms ZTE and Huawei in 2018 and 2019 respectively.

Both countries suffered from the trade and technology conflict. Since China's reform and opening-up, it has become deeply integrated into the world economic system and 
has grown into a global processing and manufacturing hub. It imports intermediate goods and raw materials from Asian economies such as Taiwan, South Korea and Japan, imports energy and other mineral goods from other resource-exporting countries, and runs a huge trade deficit with these economies in goods. After processing and manufacturing these imported intermediate goods and raw materials, China exports these goods to countries around the world, particularly to European, American and Japanese markets. China runs a large trade surplus in goods with these countries.

The United States holds key positions along global value chains (GVCs). It controls the core technology of high-tech GVCs, but also the marketing outlets of other important global value chains through brand and sales networks. American consumers enjoy low-cost and highquality imports and US multinational companies earn high operating profits, all while the United States maintains a huge trade deficit with many of its trading partners.

Taking the 2019 trade balance of goods among its top 100 trading partners as an example, China ran a trade surplus with 60 out of its top 100 trade partners, while the United States ran a deficit with 61 out of 100 . China's top 100 trading partners accounted for 95.6 per cent of Chinese total trade value in 2019, while the United States' top 100 trade partners accounted for 99.4 per cent of US total trade value.

The United States' trade war with China has severely inhibited trade in goods between the two countries. Goods that are efficiently made in China must now be manufactured in neighbouring countries, increasing production costs and lifting product prices. This hurts American consumers, who then have to pay more for the same imported goods, and American multinational companies which suffer from reduced profits.

The trade war also directly reduces the scale of US-China bilateral trade. In 2018, China was the United States' largest bilateral trade partner, with two-way trade valued at US\$659.8 billion-greater than the United States' trade with Canada, Mexico and the European Union (excluding the United Kingdom). With the trade war under way, in 2019 the value of Chinese goods trade with the United States fell by US $\$ 101$ billion and China fell to fourth place in trade with the United States (behind the European Union, Mexico and Canada).

A $\mathrm{N}$ international system based on multilateralism and rules is a valuable but fragile global public good. Unilateralism among great powers, especially countries with potential hegemonic power, will not only cause both sides to lose, but also undermine the rules-based international order and lead to the collapse of multilateralism. Unilateralism by any one great power will trigger retaliation from others. The threat of bilateral retaliation and sanctions will continue to escalate under these conditions.

China finds itself in a dilemma over its increasing trade and technology tensions with the United States: if it does not respond and instead chooses to wait for intervention from the World Trade Organization (WTO), it will have to wait for a long time for any real action. It took two years for the WTO to rule that the Section 301 tariff imposed by the United States on China was illegal. It would take even longer to rectify US wrongdoing.

During this process, China would suffer losses inflicted by the United States. This effect would only intensify over time. If China undertakes titfor-tat measures, it will gradually deviate from multilateralism and move towards bilateralism. This is the mechanism of adverse selection in the international order. Under this mechanism, the rules-based order can easily be destroyed by great-power competition.

Bilateralism would also lead to US-China economic decoupling, forcing a slide into inward-looking development, and their establishing independent and local supply chain systems. Little by little, a move towards bilateralism would produce two parallel and opposing international economic systems. This would result large costs from the investment and trade diversion effects that reduce the efficiency of the global open economy (albeit in exchange for the independence and security of each country's production and supply).

The trade and technology war between China and the United States is unfortunately moving in this direction. Even if the United States had launched the 301 action earlier, or China had chosen to respond and retaliate later, the final result would have been the same. Both countries will slide from multilateralism to bilateralism, and from a rules-based system to a power-based system.

The world's great powers should bear in mind their international responsibilities. Great powers should try to avoid unilateralism, and instead use dialogue and cooperation to deal with bilateral problems. EAFQ

Song Hong is a Senior Fellow, Professor and Deputy Director-General at the Institute of American Studies, the Chinese Academy of Social Sciences (CASS). 


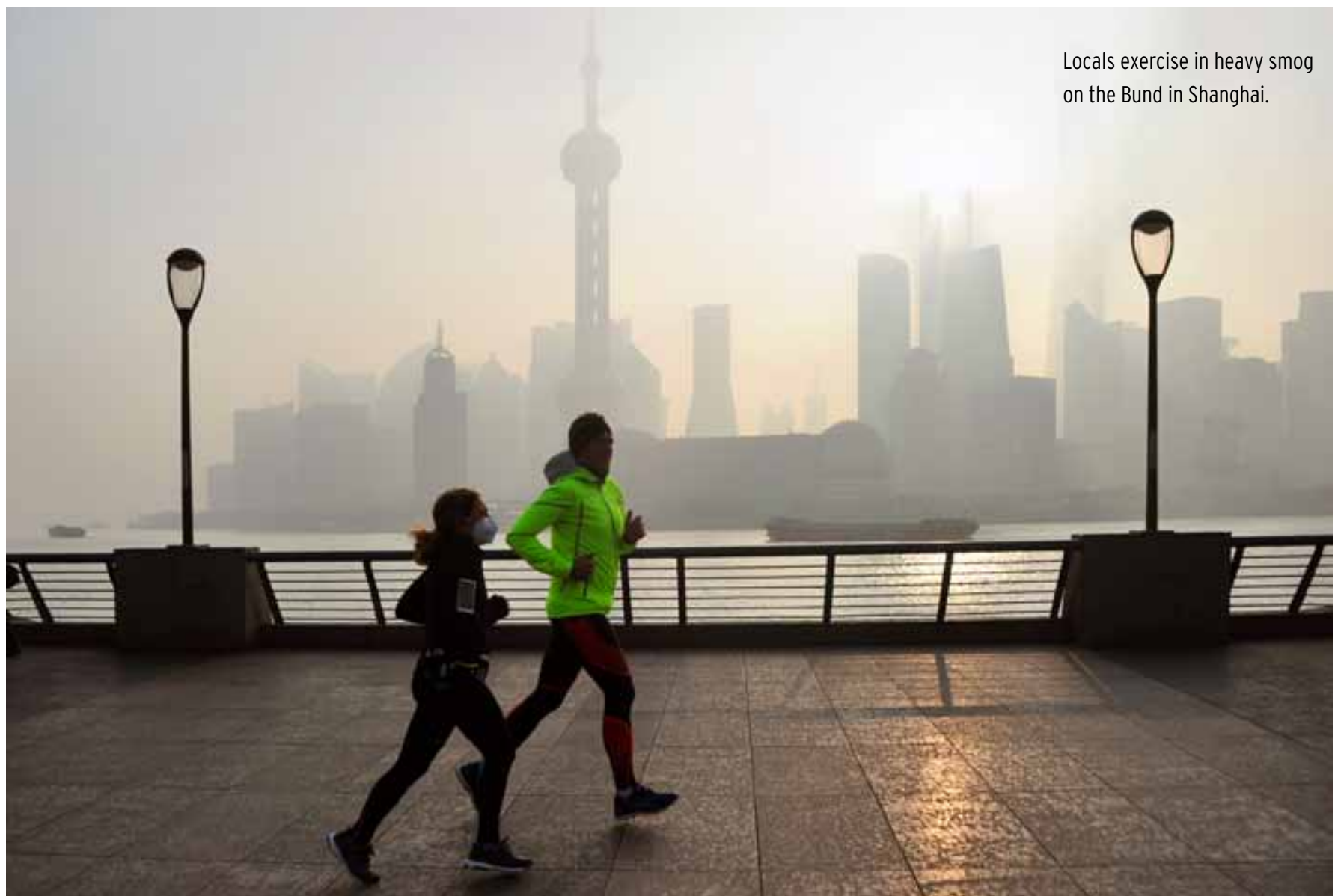

\section{Questions remain over 'eco-civilisation' ambitions}

\section{ISABEL HILTON}

$\mathbf{0}$ N 22 September 2020, a year already dominated by the unexpected, China's President and Communist Party General Secretary, $\mathrm{Xi}$ Jinping, delivered a surprise that was more widely welcomed than many of the year's events. Speaking by video link to the UN General Assembly, Xi announced that China was setting a target for carbon neutrality by 2060 and that the country's emissions would peak before 2030 .

The second promise was only a marginal advance on the pledge made in Paris in 2015, when China promised its emissions would peak by 2030 'or earlier'. That had been hailed at the time as a breakthrough, although Chinese modellers would privately admit that China had the capacity to peak as early as 2022-2023. In keeping with Chinese practice, a modest promise easily kept is preferable to an ambitious one that might be missed.

In the heady post-Paris Agreement days, China's signing up as a full participant seemed to be enough for Beijing to win praise in the global climate community. That was reinforced when the then freshly elected US President Donald Trump announced he was ordering the United States to withdraw from the agreement. In Davos in February 2017, $\mathrm{Xi}$ reassured his elite audience that China would continue to honour its international commitments.

But what did those commitments add up to and how deeply was Xi engaged in China's climate policy?

When Xi took power in 2012, the climate and environmental impacts of China's industrial development model 
had reached crisis point: air, water and soil pollution were costing millions of lives, and China's carbon emissionsby then already the world's largestcontinued to climb steeply.

The costs of China's turbo-charged growth were inescapable, but for much of the 2000s China under president $\mathrm{Hu}$ Jintao and premier Wen Jiabao maintained that the country could not yet afford to take care of the environment and that, as a non-Annex One signatory of the Kyoto Protocol, China's climate obligations were limited. 'Pollute first, clean up later, if not an official regime slogan, was an oft-repeated guiding principle.

At the same time, the industrial policies that had so far powered China's rise were running out of steam: margins were thin, debt was climbing, damaging externalities were eroding government credibility and China's competitive advantages-especially in cheap labour-were disappearing.

As the government machine began to work on the 12th Five Year Plan, launched in 2011, the need to move up the value chain and create a more efficient, higher-value economy dovetailed neatly with the other policy goals of controlling emissions and escaping the middle income trap. China began to invest in the lowcarbon technologies that it hoped would power its future prosperity and commenced a long upgrade of its energy sector to make it cleaner and more efficient.

Today, Xi's regime slogan is 'ecocivilisation', the proposition that economic, industrial, agricultural, cultural and social norms must serve a goal of sustainability. He did not invent the term but in 2012, the year he came to power, it was written into the Chinese Communist Party constitution. Since then Xi has reinforced it as a guiding principle of
China's industrial economy.

At the same time, China's propagandists have aimed to polish Xi's claims to environmental leadership, attributing to him the authorship of the "two mountains theory'-in reality, like eco-civilisation, it is an idea with a long prehistory. Nevertheless, the theory neatly encapsulates this phase of China's climate and environmental planning and its ambition to combine an overdue economic upgrade with climate-related economic opportunity.

$\mathrm{Xi}$ will have presided over three Five Year Plans by 2021: the 12th (20112016) was underway when he became leader, the 13th was devised under his leadership and the 14th will be unveiled early in 2021. Over the course of these three plans the commitment to low-carbon technologies and a transition towards greener growth in China's domestic economy has steadily grown.

This has been achieved by targeted investment in low-carbon technologies, including electric vehicles, batteries, solar and wind power, and a set of targets related

\section{Despite the COVID-}

\section{9-induced economic}

slowdown, China's

emissions have not yet

peaked, and the country's

post-pandemic stimulus

package is more brown

than green to energy density, afforestation and increasing the non-fossil-fuel primary energy target. Other green measures include the slow development of an as-yet limited carbon market and experimentation in circular-economy projects.

China's political economy has been characterised as 'fragmented authoritarianism, a description that captures, among other characteristics, the regime's difficulties in ensuring that its declared policies are executed at lower levels of government. This is particularly evident where policies intended to protect the environment are in conflict at local and provincial levels with competing and more highly weighted demands to grow the economy.

Under $\mathrm{Hu}$ and Wen, officials in a weak environment ministry leant on the power of sympathetic journalists and China's emerging environmental civil society for support as official environmental efforts frequently suffered pushback from powerful vested interests. Under Xi Jinping, as others have noted, the regime has become notably more authoritarian than that of his immediate predecessors: reforms to the state management of China's lively environmental NGOs have tightened state supervision and stricter controls of both formal and social media

have severely restricted the power of journalism to expose environmental wrongdoing.

Xi's approach has been described as 'eco-authoritarianism', favouring centrally directed measures to ensure bureaucratic compliance over other approaches, such as investigative journalism and class action lawsuits. Instead, Xi's regime has undertaken repeated administrative reforms, including upgraded and high-profile inspections-modelled on the much- 


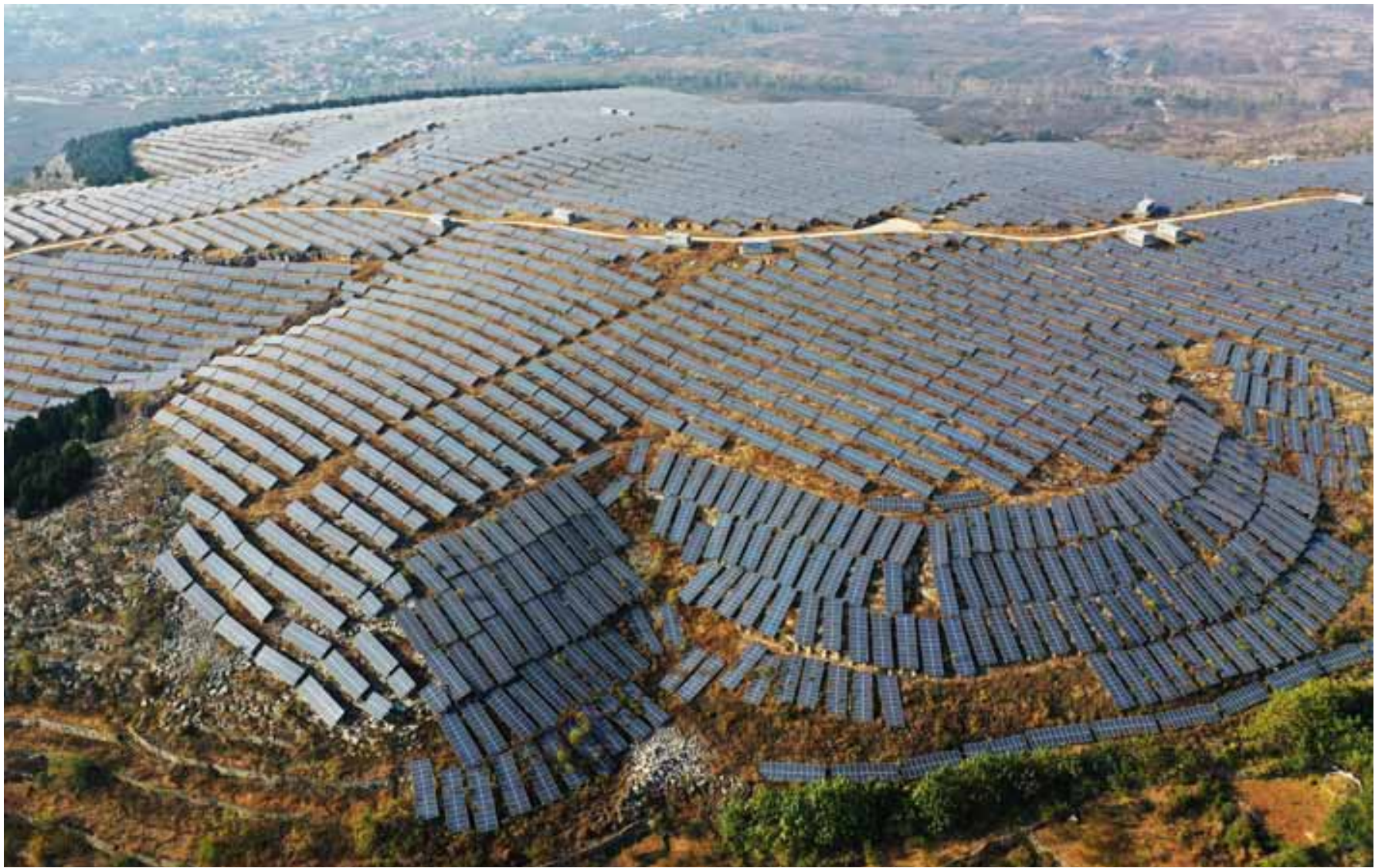

An aerial view of photovoltaic panels at Shandong's Longyashan Mountain. China's commitment to greener technology in the domestic economy has grown.

feared anti-corruption inspections-to expose polluting enterprises and to link responsibility for local pollution to local officials who now carry lifetime responsibility for pollution that they permit to take place.

Promotion prospects, too, can now be affected by environmental

\section{EASTASIAFORUM}

Quarterly

OUR NEXT ISSUE ...

\section{Asia after the US elections}

failures with the introduction of lifetime responsibility-no longer can an official escape the consequences by moving on to another post.

Several rounds of legal reform have greatly increased the penalties that enterprises face for environmental violations. A reorganisation of ministries in 2018 upgraded the powers and reach of a new Ministry of Ecology and Environment, rationalising many previously siloed and fragmented enforcement powers. The ministry now has responsibility for climate change, which was previously within the purview of the National Development and Reform Commission.

Results in some areas have been clear-air quality, at least in the eastern cities, has notably improvedbut in others large questions remain.
Despite the COVID-19-induced economic slowdown, China's emissions have not yet peaked, and the country's post-pandemic stimulus package is more brown than green, despite the regime's claim to green leadership. Moreover, China continues to build substantial numbers of new coal-fired power plants at home and, damagingly, overseas.

If Xi's 2060 target is to be met, China's continuing dependence on coal will be among the biggest challenges. If $\mathrm{Xi}$ is truly to claim climate leadership, he must ensure that China's overseas investments are brought into alignment with the global ambitions of the Paris Agreement. EAFQ

\section{Isabel Hilton is CEO and Editor of China Dialogue.}




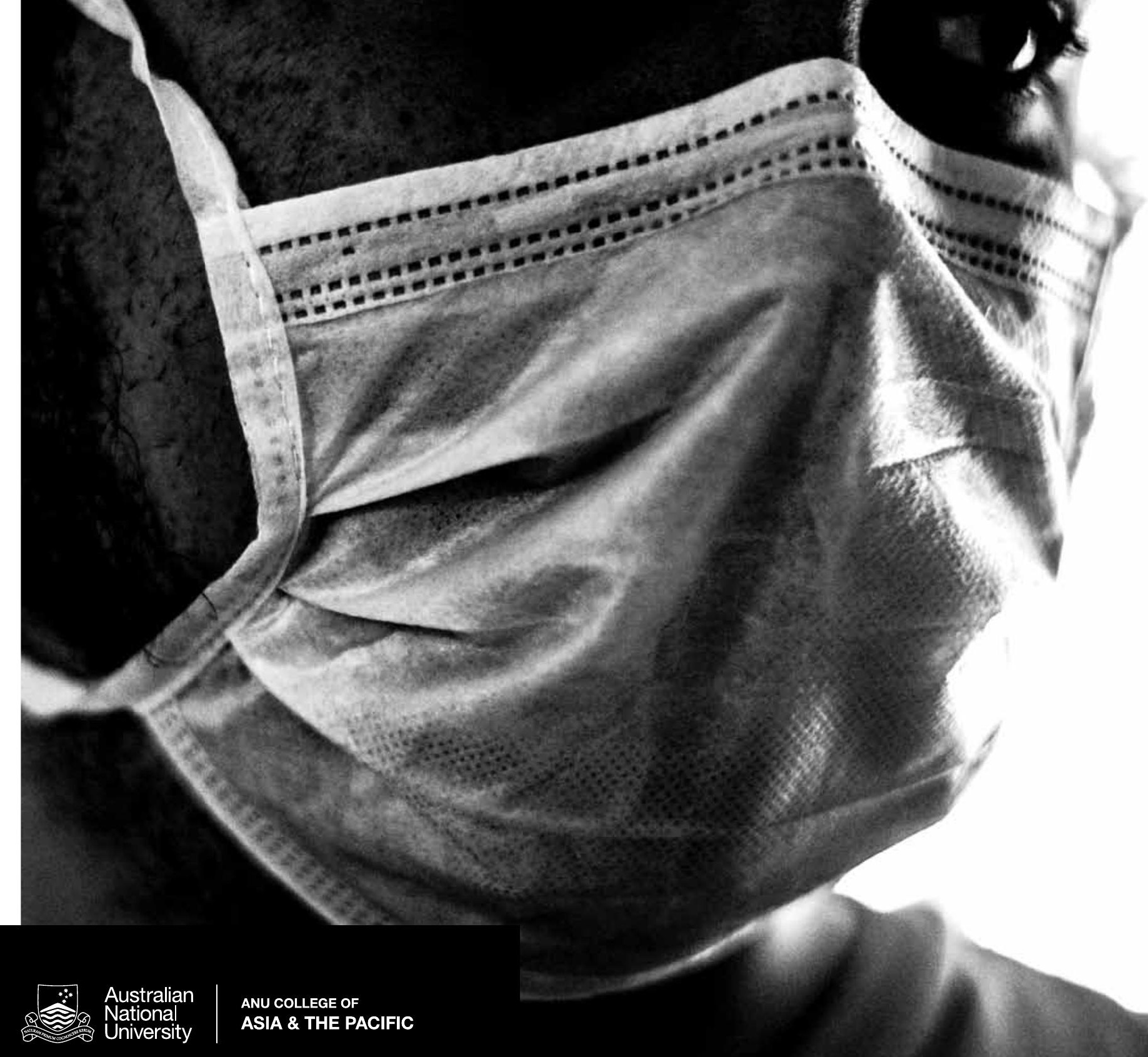

\section{There has never been a more urgent time to use research to shape public debate, policy decisions and the well-being of our society.}

Connect with us

asiapacific.anu.edu.au

$f y \square$ 요 